\title{
Plant Molecular Farming: A Viable Platform for Recombinant Biopharmaceutical Production
}

\author{
Balamurugan Shanmugaraj ${ }^{1,2}$, Christine Joy I. Bulaon ${ }^{2}$ and Waranyoo Phoolcharoen ${ }^{1,2, *(D)}$ \\ 1 Research Unit for Plant-Produced Pharmaceuticals, Chulalongkorn University, Bangkok 10330, Thailand; \\ Balamurugan.S@chula.ac.th \\ 2 Department of Pharmacognosy and Pharmaceutical Botany, Faculty of Pharmaceutical Sciences \\ Chulalongkorn University, Bangkok 10330, Thailand; 6176101033@student.chula.ac.th \\ * Correspondence: Waranyoo.P@chula.ac.th; Tel.: +66-2-218-8359; Fax: +66-2-218-8357
}

Received: 1 May 2020; Accepted: 30 June 2020; Published: 4 July 2020

\begin{abstract}
The demand for recombinant proteins in terms of quality, quantity, and diversity is increasing steadily, which is attracting global attention for the development of new recombinant protein production technologies and the engineering of conventional established expression systems based on bacteria or mammalian cell cultures. Since the advancements of plant genetic engineering in the 1980s, plants have been used for the production of economically valuable, biologically active non-native proteins or biopharmaceuticals, the concept termed as plant molecular farming (PMF). PMF is considered as a cost-effective technology that has grown and advanced tremendously over the past two decades. The development and improvement of the transient expression system has significantly reduced the protein production timeline and greatly improved the protein yield in plants. The major factors that drive the plant-based platform towards potential competitors for the conventional expression system are cost-effectiveness, scalability, flexibility, versatility, and robustness of the system. Many biopharmaceuticals including recombinant vaccine antigens, monoclonal antibodies, and other commercially viable proteins are produced in plants, some of which are in the pre-clinical and clinical pipeline. In this review, we consider the importance of a plant- based production system for recombinant protein production, and its potential to produce biopharmaceuticals is discussed.
\end{abstract}

Keywords: biopharmaceuticals; molecular farming; Nicotiana; plant production system; plant-derived protein; recombinant protein; transient expression

\section{Introduction}

Recombinant proteins are complex exogenous ("foreign") proteins that are produced in expression hosts, and mainly used as medical diagnostic reagents and in human healthcare as vaccines, drugs, or monoclonal antibodies [1]. The prominent role and increasing market demand for high-value recombinant proteins in novel drug discovery creates an opportunity for the development of various protein expression hosts to manufacture proteins by following the existing rigid standards laid down for veterinary and human applications. The industry is focusing mainly on already established production platforms using prokaryotic and eukaryotic expression host systems such as Escherichia coli, a selection of yeast, insect, and mammalian cell cultures, due to their well-defined processes in-line with current good manufacturing practice (cGMP) [2]. Moreover, industrially established mammalian and other cell cultures have stringent regulatory approval in place, which hinders the industrial acceptance of the new technology or production system. Bacterial expression systems offer rapid production with high product yield, whereas Saccharomyces cerevisiae and Pichia pastoris (yeast) offer post-translational modifications (PTMs) which are essential for functional activity of the recombinant proteins [3]. The majority of the 
approved recombinant biopharmaceuticals are produced in mammalian cell lines [4]. However, all the production systems have their own merits and setbacks such as production time, high operating costs, protein yield, chances of contamination with pathogenic microorganisms, limited post-translational modifications, and regulatory approval. In order to compete with the established platform, the new expression system must have unique advantages that can overcome the limitations of the existing ones. Plants offer several potential benefits over conventional expression platforms and prove the reliability of the system for the production of highly valuable proteins. Advancements in plant molecular farming approaches in the recent decade have made plants an attractive manufacturing system that can even achieve commercially relevant production levels in a short period $[1,5,6]$. As the progress is continuously being made in this ever-growing field, here in this review, we summarize the importance and prospects of plant expression systems for the cost-effective production of recombinant proteins. Potential vaccine candidates, monoclonal antibodies, and industrial enzymes expressed in plants are also described.

\section{Plant Expression Platform}

Plants were utilized for the expression of recombinant proteins from the late 1980s [7]. Since then, the plant expression platform has faced several hurdles, until recently the first plant-based product "Elelyso" was commercialized by Protalix Biotherapeutics for the treatment of Gaucher's disease in 2012 [8]. The practice of using plants for high-value recombinant protein production ranging from pharmaceutical therapeutics to non-pharmaceutical products such as antibodies, vaccine antigens, enzymes, growth factors, research or diagnostic reagents, and cosmetic ingredients [9] has improved over time and advanced significantly in recent decades, which in turn has led to a major paradigm shift in the pharmaceutical sector. The technology has rapidly developed, and the potential drawbacks associated with plant molecular farming during their early stages of development, including the need for a high protein expression level and efficient downstream processing, have now been achieved. The advantages of plant expression platforms are cited in several earlier reports showing head-to-head comparisons with other existing platforms (Table 1) [10-18]. The key advantages of all plant-based systems are easy cultivation, low expenses, low or no pathogen load, rapid mass production of recombinant proteins, and the ability of the plants to assemble complex proteins with eukaryotic-like post-translational modifications (PTMs) [19].

Protein folding is highly essential to retain the biological activity of the recombinant therapeutic proteins. Due to the lack of the protein processing complex and limited capacity for PTMs, proper protein folding cannot be achieved in the prokaryotic expression system [20]. Plants have the capacity to assemble and perform PTMs of large multimeric proteins required for their functional biological activity. However, plants lack the authentic human $N$-glycosylation processing mechanism which has been overcome by the glycoengineering approaches towards the synthesis of targeted human and non-human structures to increase product homogeneity, quality, and quantity [21,22].

The Nicotiana genus is often used for genetic transformation studies due to its growth rate and easy genetic manipulation. Most of the recombinant proteins such as pharmaceuticals, vaccines, hormones, cytokines, growth regulators, and industrial products are produced in tobacco, which is considered as a molecular biology workhouse of the plant world. Nicotiana benthamiana and N. tabacum are two common species used for the stable and transient expression of recombinant proteins. Further, several cereal crops, fruits, and vegetables such as rice, maize, lettuce, tomato, potato, and alfalfa were also evaluated for their applicability in plant molecular farming (PMF) depending on the protein target and application [1]. Many plant-produced therapeutic proteins are in pre-clinical and clinical trials and are close to commercialization $[23,24]$. The strength and bottlenecks of the commercial potential of the plant expression system was critically reviewed and summarized by Schillberg et al. (2019) [2]. 
Table 1. Available expression platforms for recombinant protein production with potential advantages and disadvantages (adapted from Shanmugaraj et al., 2020) [25].

\begin{tabular}{|c|c|c|}
\hline $\begin{array}{l}\text { Expression } \\
\text { System }\end{array}$ & Advantages & Disadvantages \\
\hline Bacteria & $\begin{array}{c}\text { Easy to manipulate } \\
\text { Low cost } \\
\text { High expression } \\
\text { Ease of scale up } \\
\text { Short turnaround time } \\
\text { Established regulatory procedures and approval }\end{array}$ & $\begin{array}{c}\text { Improper folding } \\
\text { Lack of post-translational } \\
\text { modifications which may affect the } \\
\text { protein function } \\
\text { Endotoxin accumulation }\end{array}$ \\
\hline $\begin{array}{l}\text { Mammalian } \\
\text { Cells }\end{array}$ & $\begin{array}{c}\text { Proper folding and authentic post-translational } \\
\text { modifications } \\
\text { Existing regulatory approval }\end{array}$ & $\begin{array}{l}\text { High production cost } \\
\text { Expensive media and culture } \\
\text { condition requirements }\end{array}$ \\
\hline Yeast & $\begin{array}{c}\text { Rapid growth and scalable } \\
\text { Easy to manipulate } \\
\text { Simple and inexpensive media requirements and } \\
\text { culture conditions } \\
\text { Post-translational modifications of recombinant } \\
\text { proteins }\end{array}$ & $\begin{array}{l}\text { Difficulty in cell disruption due to } \\
\text { the thick and hard cell walls } \\
\text { Hyperglycosylation of proteins } \\
\text { Limited glycosylation capacity }\end{array}$ \\
\hline Insect cells & $\begin{array}{l}\text { High expression levels } \\
\text { Ability to produce complex proteins including } \\
\text { secreted, membrane, and intracellular proteins } \\
\text { Proper folding and post-translational modifications }\end{array}$ & $\begin{array}{l}\text { High cost and time consuming } \\
\text { Expensive media and culture } \\
\text { condition requirements }\end{array}$ \\
\hline Plant & $\begin{array}{c}\text { Rapid and affordable } \\
\text { Optimized growth conditions } \\
\text { Free from pathogen and bacterial toxin contaminants } \\
\text { Economical } \\
\text { Post-translational modification somewhat similar } \\
\text { like mammalian system }\end{array}$ & $\begin{array}{l}\text { Regulatory compliance } \\
\text { Limited glycosylation capacity }\end{array}$ \\
\hline
\end{tabular}

\section{Plant-Derived Recombinant Proteins}

The concept of using plants for the production of foreign proteins including pharmaceutical and non-pharmaceutical proteins has been well explored and documented. Many reports proved the ability of in vivo and in vitro plant systems to produce vaccine candidates both for veterinary and human applications and showed that plant-produced antigens elicit potential immune responses in animal models and even confer protection in animal challenge experiments. Examples of the variety of pharmaceutical and non-pharmaceutical proteins expressed in plant systems are illustrated in Tables 2 and 3.

Tobacco has been engineered to express a variety of antigens in the nucleus and chloroplast including, but not limited to, chikungunya, dengue, Ebola, influenza, and Zika. The transformation protocols for recombinant protein production are also established for fruits and vegetables such as tomatoes and potatoes. Transgenic potatoes expressing the S1 glycoprotein of the infectious bronchitis virus confers protection to chickens upon virus challenge [26]. Leafy crops such as lettuce, alfalfa, and clover have been investigated for molecular farming to obtain the oral delivery of vaccine antigens eliminating purification and injections. The lettuce chloroplast-derived booster vaccine using lyophilized plant cells expressing the poliovirus capsid protein induced neutralization antibodies in mice primed with inactivated poliovirus vaccine (IPV) and conferred protection against all polio serotypes [27]. Plant systems have also been evaluated for the expression of virus-like particles (VLP) of many viruses including norovirus, poliovirus, foot-and-mouth disease virus, influenza, [28-31], and the potential for plant-derived VLPs to be used as candidate vaccines and reagents has been reviewed in detail elsewhere [18,32,33]. Apart from expressing antigens for human diseases, several antigens for veterinary applications and non-pharmaceutical proteins have also been well tested 
for expression in plants, and are particularly gaining attention due to the fact that these products can quickly reach the market due to lower regulatory burden [9]. This was clearly evidenced by the commercialization of avidin [34], $\beta$-glucuronidase [35], and trypsin [36] by the US-based biotechnology company ProdiGene, Inc. The vaccine against Newcastle disease virus (NDV) was the first plant-based poultry vaccine (Dow Agrosciences) that obtained regulatory approval from the United States Department of Agriculture in 2006, opening a new avenue for the commercialization of plant-derived vaccines. Currently, many plant-derived non-pharmaceutical and pharmaceutical proteins are in clinical development.

Although proof-of-concept and efficacy of many vaccine candidates proved the feasibility and scalability of the robust plant system, it is high time to compete with the established expression systems. Now the plant-based good manufacturing practices (GMP) complaint production facilities such as Fraunhofer (Germany), Kentucky BioProcessing (USA), Medicago (Canada), and Protalix Biotherapeutics (Israel) are available to manufacture GMP materials for human clinical trials. Fraunhofer IME received a GMP license for the production of neutralizing anti-HIV antibody 2 G12 in tobacco for phase I clinical testing [37]. The plant molecular farming research community continuously thrives to set up a regulatory framework for plant-derived products.

Table 2. Selected list of vaccine candidates and antibodies expressed in plants against various diseases.

\begin{tabular}{|c|c|c|c|c|c|}
\hline \multicolumn{6}{|c|}{ Vaccine Candidates } \\
\hline $\begin{array}{l}\text { Recombinant } \\
\text { Protein }\end{array}$ & Pathogen/Disease & Expression System & Transformation Method & Expression Level & Reference \\
\hline $\begin{array}{c}\text { Hepatitis B surface } \\
\text { antigen }\end{array}$ & Hepatitis B virus & $\begin{array}{c}\text { Tobacco } \\
\text { (Nicotiana tabacum) }\end{array}$ & $\begin{array}{l}\text { Agrobacterium mediated } \\
\text { (Stable expression } \\
\text { /Nucleus) }\end{array}$ & $\begin{array}{l}66 \mathrm{ng} / \mathrm{mg} \text { of soluble } \\
\text { protein }\end{array}$ & [38] \\
\hline $\begin{array}{l}\text { Structural protein } \\
\text { VP60 }\end{array}$ & $\begin{array}{c}\quad \text { Rabbit } \\
\text { hemorrhagic } \\
\text { disease virus } \\
\quad(\text { RHDV) }\end{array}$ & $\begin{array}{c}\text { Potato } \\
\text { (Solanum tuberosum) }\end{array}$ & $\begin{array}{l}\text { Agrobacterium mediated } \\
\text { (Stable expression } \\
\text { /Nucleus) }\end{array}$ & $\begin{array}{l}0.3 \% \text { of total } \\
\text { soluble protein }\end{array}$ & [39] \\
\hline $\begin{array}{c}\text { Spike }(\mathrm{S}) \text { protein of } \\
\text { transmissible } \\
\text { gastroenteritis } \\
\text { virus }\end{array}$ & $\begin{array}{l}\text { Transmissible } \\
\text { gastroenteritis } \\
\text { virus (TGEV) }\end{array}$ & $\begin{array}{c}\text { Tobacco } \\
\text { (Nicotiana tabacum) }\end{array}$ & $\begin{array}{c}\text { Agrobacterium mediated } \\
\text { (Stable expression } \\
\text { /Nucleus) }\end{array}$ & $\begin{array}{l}0.1-0.2 \% \text { of total } \\
\text { soluble protein }\end{array}$ & [40] \\
\hline $\begin{array}{l}\text { Hemagglutinin } \\
\text { protein of } \\
\text { rinderpest virus }\end{array}$ & $\begin{array}{l}\text { Rinderpest virus } \\
\text { (RPV) }\end{array}$ & $\begin{array}{c}\text { Peanut } \\
\text { (Arachis hypogea L.) }\end{array}$ & $\begin{array}{c}\text { Agrobacterium mediated } \\
\text { (Stable expression } \\
\text { /Nucleus) }\end{array}$ & $\begin{array}{l}0.2-1.3 \% \text { of total } \\
\text { soluble protein }\end{array}$ & {$[41]$} \\
\hline $\begin{array}{l}\text { Glycoprotein D } \\
\text { (gD) of bovine } \\
\text { herpes virus }\end{array}$ & $\begin{array}{l}\text { Bovine herpes } \\
\text { virus }\end{array}$ & $\begin{array}{c}\text { Tobacco } \\
\text { (Nicotiana benthamiana) }\end{array}$ & $\begin{array}{c}\text { Mechanical inoculation } \\
\text { (Stable expression } \\
\text { /Nucleus) }\end{array}$ & $\begin{array}{l}20 \mu \mathrm{g} / \mathrm{g} \text { fresh } \\
\text { weight }(\mathrm{FW})\end{array}$ & [42] \\
\hline $\begin{array}{l}\text { L1 major capsid } \\
\text { protein }\end{array}$ & $\begin{array}{c}\text { Human } \\
\text { papillomavirus }\end{array}$ & $\begin{array}{c}\text { Tobacco } \\
\text { (Nicotiana tabacum) }\end{array}$ & $\begin{array}{c}\text { Agrobacterium mediated } \\
\text { (Stable expression } \\
\text { /Nucleus) }\end{array}$ & $2-4 \mu \mathrm{g} / \mathrm{kg} \mathrm{FW}$ & [43] \\
\hline $\begin{array}{l}\text { Spike }(S) \text { protein of } \\
\text { transmissible } \\
\text { gastroenteritis } \\
\text { virus }\end{array}$ & $\begin{array}{l}\text { Transmissible } \\
\text { gastroenteritis } \\
\text { virus (TGEV) }\end{array}$ & Corn (Zea mays) & $\begin{array}{l}\text { Agrobacterium mediated } \\
\text { (Stable expression } \\
\text { /Nucleus) }\end{array}$ & $13 \mathrm{mg} / \mathrm{kg} \mathrm{FW}$ & [44] \\
\hline $\begin{array}{l}\text { Spike }(S) \text { protein of } \\
\text { infectious } \\
\text { bronchitis virus }\end{array}$ & $\begin{array}{l}\text { Infectious } \\
\text { bronchitis virus } \\
\text { (IBV) }\end{array}$ & $\begin{array}{c}\text { Potato } \\
\text { (Solanum tuberosum) }\end{array}$ & $\begin{array}{c}\text { Agrobacterium mediated } \\
\text { (Stable expression } \\
\text { /Nucleus) }\end{array}$ & $2.39-2.53 \mu \mathrm{g} / \mathrm{g} F W$ & [26] \\
\hline $\begin{array}{l}\text { Anthrax protective } \\
\text { antigen (PA) }\end{array}$ & Anthrax & $\begin{array}{c}\text { Tobacco } \\
\text { (Nicotiana tabacum) }\end{array}$ & $\begin{array}{l}\text { Biolistic method (Stable } \\
\text { expression/Chloroplast) }\end{array}$ & $\begin{array}{c}14.2 \% \text { of total } \\
\text { soluble protein }\end{array}$ & [45] \\
\hline $\begin{array}{l}\text { Hepatitis B virus } \\
\text { surface antigen }\end{array}$ & $\begin{array}{l}\text { Hepatitis B virus } \\
\text { (HBV) }\end{array}$ & $\begin{array}{c}\text { Potato } \\
\text { (Solanum tuberosum) }\end{array}$ & $\begin{array}{c}\text { Agrobacterium mediated } \\
\text { (Stable expression } \\
\text { /Nucleus) }\end{array}$ & $8.5 \mu \mathrm{g} / \mathrm{g}$ FW & [46] \\
\hline $\begin{array}{l}\text { Fusion }(\mathrm{F}) \text { protein } \\
\text { of Newcastle } \\
\text { disease virus }\end{array}$ & $\begin{array}{l}\text { Newcastle disease } \\
\text { virus (NDV) }\end{array}$ & Corn (Zea mays L.) & $\begin{array}{l}\text { Biolistic method (Stable } \\
\text { expression/Chloroplast) }\end{array}$ & $\begin{array}{l}3.0 \% \text { of total } \\
\text { soluble protein }\end{array}$ & [47] \\
\hline
\end{tabular}


Table 2. Cont.

\begin{tabular}{|c|c|c|c|c|c|}
\hline \multicolumn{6}{|c|}{ Vaccine Candidates } \\
\hline $\begin{array}{l}\text { Recombinant } \\
\text { Protein }\end{array}$ & Pathogen/Disease & Expression System & Transformation Method & Expression Level & Reference \\
\hline $\begin{array}{c}\text { F4 fimbrial adhesin } \\
\text { FaeG }\end{array}$ & $\begin{array}{l}\text { Enterotoxigenic } E \text {. } \\
\text { coli }\end{array}$ & $\begin{array}{l}\text { Alfalfa (Medicago } \\
\text { sativa L.) }\end{array}$ & $\begin{array}{c}\text { Agrobacterium mediated } \\
\text { (Stable expression/ } \\
\text { Chloroplast) }\end{array}$ & $\begin{array}{l}1.0 \% \text { of total } \\
\text { soluble protein }\end{array}$ & [48] \\
\hline $\begin{array}{l}\text { L1 capsid protein } \\
\text { gene }\end{array}$ & $\begin{array}{l}\text { Cottontail rabbit } \\
\text { papillomavirus }\end{array}$ & $\begin{array}{c}\text { Tobacco } \\
\text { (Nicotiana tabacum) }\end{array}$ & $\begin{array}{c}\text { Agrobacterium mediated } \\
\text { (Stable expression } \\
\text { /Nucleus) }\end{array}$ & $\begin{array}{l}0.4-1 \mathrm{mg} / \mathrm{kg} \text { of } \\
\text { total leaf mass }\end{array}$ & [49] \\
\hline $\begin{array}{l}\text { Structural protein } \\
\text { VP2 }\end{array}$ & $\begin{array}{l}\text { Infectious bursal } \\
\text { disease virus } \\
\text { (IBDV) }\end{array}$ & Rice & $\begin{array}{c}\text { Agrobacterium mediated } \\
\text { (Stable expression } \\
\text { /Nucleus) }\end{array}$ & $40.21 \mu \mathrm{g} / \mathrm{g} \mathrm{FW}$ & [50] \\
\hline $\begin{array}{l}\text { Hepatitis B virus } \\
\text { surface antigen }\end{array}$ & $\begin{array}{l}\text { Hepatitis B virus } \\
\text { (HBV) }\end{array}$ & $\begin{array}{c}\text { Tobacco } \\
\text { (Nicotiana benthamiana) }\end{array}$ & $\begin{array}{l}\text { Agrobacterium mediated } \\
\text { (Transient expression) }\end{array}$ & $295 \mu \mathrm{g} / \mathrm{g}$ FW & [51] \\
\hline $\begin{array}{l}\text { Haemagglutinin } \\
\text { (HA) }\end{array}$ & $\begin{array}{c}\text { H5N1 (avian } \\
\text { influenza virus) \& } \\
\text { H1N1 (human) } \\
\text { influenza strains }\end{array}$ & $\begin{array}{c}\text { Tobacco } \\
\text { (Nicotiana benthamiana) }\end{array}$ & $\begin{array}{l}\text { Agrobacterium mediated } \\
\text { (Transient expression) }\end{array}$ & $50 \mathrm{mg} / \mathrm{kg} \mathrm{FW}$ & [52] \\
\hline $\begin{array}{l}\text { Heat-labile toxin B } \\
\text { subunit (LTB) }\end{array}$ & $\begin{array}{l}\text { Enterotoxigenic } E \text {. } \\
\text { coli }\end{array}$ & $\begin{array}{c}\text { Carrot } \\
(\text { Daucus carota })\end{array}$ & $\begin{array}{l}\text { Agrobacterium mediated } \\
\text { (Stable expression } \\
\text { /Nucleus) }\end{array}$ & $\begin{array}{l}0.3 \% \text { of total } \\
\text { soluble protein }\end{array}$ & [53] \\
\hline $\begin{array}{l}\text { Norwalk virus } \\
\text { capsid protein }\end{array}$ & Norwalk virus & $\begin{array}{c}\text { Tobacco } \\
\text { (Nicotiana benthamiana) }\end{array}$ & $\begin{array}{l}\text { Agrobacterium mediated } \\
\text { (Transient expression) }\end{array}$ & $0.8 \mathrm{mg} / \mathrm{g}$ FW & [54] \\
\hline $\begin{array}{c}\text { Structural protein } \\
\text { VP1 }\end{array}$ & $\begin{array}{l}\text { Foot-and-mouth } \\
\text { disease virus } \\
\text { (FMDV) }\end{array}$ & $\begin{array}{l}\text { Legume (Stylosanthes } \\
\text { guianensis) }\end{array}$ & $\begin{array}{c}\text { Agrobacterium mediated } \\
\text { (Stable expression } \\
\text { /Nucleus) }\end{array}$ & $\begin{array}{l}0.1-0.5 \% \text { of total } \\
\text { soluble protein }\end{array}$ & [55] \\
\hline $\begin{array}{l}\text { HIV-1 Pr55gag } \\
\text { Polyprotein }\end{array}$ & $\begin{array}{l}\text { Human } \\
\text { immunodeficiency } \\
\text { virus type } 1(\mathrm{HIV})\end{array}$ & $\begin{array}{c}\text { Tobacco } \\
\text { (Nicotiana tabacum) }\end{array}$ & $\begin{array}{l}\text { Biolistic method (Stable } \\
\text { expression/Chloroplast) }\end{array}$ & $312-363 \mathrm{mg} / \mathrm{kg}$ FW & [56] \\
\hline $\begin{array}{c}\text { Japanese } \\
\text { encephalitis virus } \\
\text { (JEV) envelope } \\
\text { protein (E) }\end{array}$ & $\begin{array}{c}\text { Japanese } \\
\text { encephalitis virus }\end{array}$ & $\begin{array}{l}\text { Japonica rice } \\
\text { (Nipponbare) }\end{array}$ & $\begin{array}{c}\text { Agrobacterium mediated } \\
\text { (Stable expression } \\
\text { /Nucleus) }\end{array}$ & $\begin{array}{l}1.1-1.9 \mu \mathrm{g} / \mathrm{mg} \text { of } \\
\text { total soluble } \\
\text { protein }\end{array}$ & [57] \\
\hline $\begin{array}{l}\text { Hemagglutinin } \\
\text { (HA) }\end{array}$ & $\begin{array}{l}\text { Avian influenza } \\
\quad(\mathrm{H} 5 \mathrm{~N} 1)\end{array}$ & $\begin{array}{c}\text { Tobacco } \\
\text { (Nicotiana benthamiana) }\end{array}$ & $\begin{array}{l}\text { Agrobacterium mediated } \\
\text { (Transient expression) }\end{array}$ & $0.3 \mathrm{~g} / \mathrm{kg}$ FW & [58] \\
\hline $\begin{array}{l}\text { Haemagglutinin } \\
\text { (HA) }\end{array}$ & Influenza virus & $\begin{array}{c}\text { Tobacco } \\
\text { (Nicotiana benthamiana) }\end{array}$ & $\begin{array}{l}\text { Agrobacterium mediated } \\
\text { (Transient expression) }\end{array}$ & $400-1300 \mathrm{mg} / \mathrm{kg} \mathrm{FW}$ & [59] \\
\hline $\begin{array}{l}\text { Haemagglutinin } \\
\text { (HA) }\end{array}$ & $\begin{array}{c}\text { Avian influenza A } \\
\text { (H7N7) }\end{array}$ & $\begin{array}{c}\text { Tobacco } \\
\text { (Nicotiana benthamiana) }\end{array}$ & $\begin{array}{l}\text { Agrobacterium mediated } \\
\text { (Transient expression) }\end{array}$ & $0.2 \mathrm{~g} / \mathrm{kg}$ FW & {$[60]$} \\
\hline $\begin{array}{c}\text { Structural protein } \\
\text { VP2 }\end{array}$ & $\begin{array}{c}\text { Infectious bursal } \\
\text { disease virus } \\
\text { (IBDV) }\end{array}$ & $\begin{array}{c}\text { Tobacco } \\
\text { (Nicotiana benthamiana) }\end{array}$ & $\begin{array}{l}\text { Agrobacterium mediated } \\
\text { (Transient expression) }\end{array}$ & $\begin{array}{l}1.0 \% \text { of total } \\
\text { soluble protein }\end{array}$ & {$[61]$} \\
\hline $\begin{array}{l}\text { Structural protein } \\
\text { E2 }\end{array}$ & $\begin{array}{l}\text { Bovine viral } \\
\text { diarrhea virus } \\
\text { (BVDV) }\end{array}$ & $\begin{array}{l}\text { Alfalfa (Medicago } \\
\text { sativa L.) }\end{array}$ & $\begin{array}{c}\text { Agrobacterium mediated } \\
\text { (Stable expression } \\
\text { /Nucleus) }\end{array}$ & $1 \mu \mathrm{g} / \mathrm{g}$ FW & {$[62]$} \\
\hline $\begin{array}{c}\text { Bluetongue } \\
\text { virus-like particles }\end{array}$ & Bluetongue virus & $\begin{array}{c}\text { Tobacco } \\
\text { (Nicotiana benthamiana) }\end{array}$ & $\begin{array}{l}\text { Agrobacterium mediated } \\
\text { (Transient expression) }\end{array}$ & $70 \mathrm{mg} / \mathrm{kg} \mathrm{FW}$ & {$[63]$} \\
\hline $\begin{array}{c}\text { Narita } 104 \text { virus } \\
\text { virus-like particles }\end{array}$ & Narita 104 virus & $\begin{array}{c}\text { Tobacco } \\
\text { (Nicotiana benthamiana) }\end{array}$ & $\begin{array}{l}\text { Agrobacterium mediated } \\
\text { (Transient expression) }\end{array}$ & $0.3 \mathrm{mg} / \mathrm{g} \mathrm{FW}$ & [64] \\
\hline $\begin{array}{c}\text { Glycoprotein (GP) } \\
\text { of PRRSV }\end{array}$ & $\begin{array}{l}\text { Porcine } \\
\text { reproductive and } \\
\text { respiratory } \\
\text { syndrome virus } \\
(\text { PRRSV) }\end{array}$ & Arabidopsis thaliana & $\begin{array}{l}\text { Agrobacterium mediated } \\
\text { (Stable expression } \\
\text { /Nucleus) }\end{array}$ & $\begin{array}{l}2.74 \% \text { of total } \\
\text { soluble protein }\end{array}$ & {$[65]$} \\
\hline $\begin{array}{l}\text { Matrix protein } 2 \\
\text { ectodomain (M2e) }\end{array}$ & $\begin{array}{l}\text { Avian influenza } \\
\qquad(\mathrm{H} 5 \mathrm{~N} 1)\end{array}$ & $\begin{array}{l}\text { Duckweed (Lemna } \\
\text { minor) }\end{array}$ & $\begin{array}{c}\text { Agrobacterium mediated } \\
\text { (Stable expression } \\
\text { /Nucleus) }\end{array}$ & 90-970 mg/kg FW & {$[66]$} \\
\hline
\end{tabular}


Table 2. Cont.

\begin{tabular}{|c|c|c|c|c|c|}
\hline \multicolumn{6}{|c|}{ Vaccine Candidates } \\
\hline $\begin{array}{l}\text { Recombinant } \\
\text { Protein }\end{array}$ & Pathogen/Disease & Expression System & Transformation Method & Expression Level & Reference \\
\hline $\begin{array}{l}\text { Matrix protein } 2 \\
\text { ectodomain (M2e) }\end{array}$ & $\begin{array}{l}\text { Avian influenza } \\
\quad(\mathrm{H} 5 \mathrm{~N} 1)\end{array}$ & $\begin{array}{c}\text { Tobacco } \\
\text { (Nicotiana benthamiana) }\end{array}$ & $\begin{array}{l}\text { Agrobacterium mediated } \\
\text { (Transient expression) }\end{array}$ & 125-205 mg/kg FW & [67] \\
\hline $\begin{array}{l}\text { Consensus domain } \\
\text { III of dengue virus } \\
\text { E glycoprotein } \\
\text { (cEDIII) }\end{array}$ & Dengue virus & $\begin{array}{c}\text { Tobacco } \\
\text { (Nicotiana benthamiana) }\end{array}$ & $\begin{array}{l}\text { Agrobacterium mediated } \\
\text { (Transient expression) }\end{array}$ & $5.2 \mathrm{mg} / \mathrm{g} \mathrm{FW}$ & {$[68]$} \\
\hline $\begin{array}{l}\text { Dengue envelop } \\
\text { protein domain III } \\
\text { (EDIII) }\end{array}$ & Dengue virus & $\begin{array}{c}\text { Tobacco } \\
\text { (Nicotiana tabacum) }\end{array}$ & $\begin{array}{l}\text { Biolistic method (Stable } \\
\text { expression/Chloroplast) }\end{array}$ & $\begin{array}{l}0.8-1.6 \% \text { of total } \\
\text { soluble protein }\end{array}$ & [69] \\
\hline PV3 VLPs & Poliovirus (PV) & $\begin{array}{c}\text { Tobacco } \\
\text { (Nicotiana benthamiana) }\end{array}$ & $\begin{array}{l}\text { Agrobacterium mediated } \\
\text { (Transient expression) }\end{array}$ & $60 \mathrm{mg} / \mathrm{kg} \mathrm{FW}$ & [28] \\
\hline $\begin{array}{c}\text { E. maxima } \\
\text { gametocyte antigen } \\
(\text { Gam82) }\end{array}$ & Eimeria maxima & $\begin{array}{c}\text { Tobacco } \\
\text { (Nicotiana tabacum) }\end{array}$ & $\begin{array}{l}\text { Agrobacterium mediated } \\
\text { (Transient expression) }\end{array}$ & $20 \mathrm{mg} / \mathrm{kg} \mathrm{FW}$ & [70] \\
\hline CHIKV E1 and E2 & Chikungunya virus & $\begin{array}{c}\text { Tobacco } \\
\text { (Nicotiana benthamiana) }\end{array}$ & $\begin{array}{l}\text { Agrobacterium mediated } \\
\text { (Transient expression) }\end{array}$ & $\begin{array}{c}\text { 8-13 mg/kg of fresh } \\
\text { leaf weight }\end{array}$ & [71] \\
\hline $\begin{array}{l}\text { ZIKV envelope }(\mathrm{E}) \\
\text { protein }\end{array}$ & Zika virus (ZIKV) & $\begin{array}{c}\text { Tobacco } \\
\text { (Nicotiana benthamiana) }\end{array}$ & $\begin{array}{l}\text { Agrobacterium mediated } \\
\text { (Transient expression) }\end{array}$ & $160 \mu \mathrm{g} / \mathrm{g} \mathrm{FW}$ & [72] \\
\hline $\begin{array}{l}\text { Porcine circovirus } \\
\text { type } 2(\mathrm{PCV}-2) \\
\text { capsid protein }\end{array}$ & $\begin{array}{l}\text { Porcine circovirus } \\
\text { type } 2\end{array}$ & $\begin{array}{c}\text { Tobacco } \\
\text { (Nicotiana benthamiana) }\end{array}$ & $\begin{array}{l}\text { Agrobacterium mediated } \\
\text { (Transient expression) }\end{array}$ & $\begin{array}{c}6.5 \mathrm{mg} / \mathrm{kg} \text { leaf wet } \\
\text { weight }\end{array}$ & [73] \\
\hline HIV Env gp140 & $\begin{array}{c}\text { Human } \\
\text { immunodeficiency } \\
\text { virus (HIV) }\end{array}$ & $\begin{array}{c}\text { Tobacco } \\
\text { (Nicotiana benthamiana) }\end{array}$ & $\begin{array}{l}\text { Agrobacterium mediated } \\
\text { (Transient expression) }\end{array}$ & 5-6 mg/kg FW & [74] \\
\hline $\begin{array}{c}\text { H6 subtype } \\
\text { haemagglutinin } \\
(\mathrm{HA})\end{array}$ & $\begin{array}{c}\text { Influenza A virus } \\
(\mathrm{H} 6 \mathrm{~N} 2)\end{array}$ & $\begin{array}{c}\text { Tobacco } \\
\text { (Nicotiana benthamiana) }\end{array}$ & $\begin{array}{l}\text { Agrobacterium mediated } \\
\text { (Transient expression) }\end{array}$ & $95 \mathrm{mg} / \mathrm{kg} \mathrm{FW}$ & [31] \\
\hline \multicolumn{6}{|c|}{ Antibodies } \\
\hline cT84.66 & $\begin{array}{c}\text { Cancer (tumor } \\
\text { marker) }\end{array}$ & $\begin{array}{c}\text { Tobacco } \\
\text { (Nicotiana tabacum) }\end{array}$ & $\begin{array}{l}\text { Agrobacterium mediated } \\
\text { (Transient expression) }\end{array}$ & $1 \mathrm{mg} / \mathrm{kg}$ FW & [75] \\
\hline scFvT84.66 & $\begin{array}{l}\text { Cancer (tumor } \\
\text { marker) }\end{array}$ & $\begin{array}{c}\text { Tobacco } \\
\text { (Nicotiana tabacum) }\end{array}$ & $\begin{array}{l}\text { Agrobacterium mediated } \\
\text { (Transient expression) }\end{array}$ & $5 \mathrm{mg} / \mathrm{kg} \mathrm{FW}$ & [75] \\
\hline scFvT84.66 & $\begin{array}{l}\text { Cancer (tumor } \\
\text { marker) }\end{array}$ & Rice (Oryza sativa) & $\begin{array}{c}\text { Biolistic method (Stable } \\
\text { expression } \\
\text { /Nucleus) }\end{array}$ & $3.8 \mu \mathrm{g} / \mathrm{g} \mathrm{FW}$ & [76] \\
\hline scFvT84.66 & $\begin{array}{l}\text { Cancer (tumor } \\
\text { marker) }\end{array}$ & $\begin{array}{c}\text { Cereal crops (wheat } \\
\text { and rice) }\end{array}$ & $\begin{array}{c}\text { Biolistic method (Stable } \\
\text { expression } \\
\text { /Nucleus) }\end{array}$ & $30 \mu \mathrm{g} / \mathrm{g}$ FW & [77] \\
\hline BR55-2 & $\begin{array}{l}\text { Human colorectal } \\
\text { cancer }\end{array}$ & $\begin{array}{c}\text { Tobacco } \\
\text { (Nicotiana tabacum) }\end{array}$ & $\begin{array}{l}\text { Agrobacterium mediated } \\
\text { (Stable expression } \\
\text { /Nucleus) }\end{array}$ & $30 \mathrm{mg} / \mathrm{kg} \mathrm{FW}$ & [78] \\
\hline $2 \mathrm{~F} 5$ & HIV & $\begin{array}{c}\text { Tobacco } \\
\text { (Nicotiana benthamiana) }\end{array}$ & $\begin{array}{c}\text { Agrobacterium mediated } \\
\text { (Stable expression } \\
\text { /Nucleus) }\end{array}$ & $\begin{array}{l}0.01 \% \text { of total } \\
\text { soluble protein }\end{array}$ & [79] \\
\hline $2 \mathrm{G} 12$ & HIV & $\begin{array}{c}\text { Tobacco } \\
\text { (Nicotiana benthamiana) }\end{array}$ & $\begin{array}{l}\text { Agrobacterium mediated } \\
\text { (Transient expression) }\end{array}$ & $0.3 \mathrm{~g} / \mathrm{kg} F W$ & [80] \\
\hline $2 \mathrm{G} 12$ & HIV & $\begin{array}{c}\text { Tobacco } \\
\text { (Nicotiana tabacum) }\end{array}$ & $\begin{array}{c}\text { Agrobacterium mediated } \\
\text { (Stable expression } \\
\text { /Nucleus) }\end{array}$ & $\begin{array}{l}8 \mathrm{mg} / \mathrm{L} \text { culture } \\
\text { medium }\end{array}$ & [81] \\
\hline $6 \mathrm{D} 8$ & Ebola virus & $\begin{array}{c}\text { Tobacco } \\
\text { (Nicotiana benthamiana) }\end{array}$ & $\begin{array}{l}\text { Agrobacterium mediated } \\
\text { (Transient expression) }\end{array}$ & $0.5 \mathrm{mg} / \mathrm{g}$ FW & [82] \\
\hline $6 \mathrm{D} 8$ & Ebola virus & $\begin{array}{l}\text { Lettuce } \\
\text { (L. sativa) }\end{array}$ & $\begin{array}{l}\text { Agrobacterium mediated } \\
\text { (Transient expression) }\end{array}$ & $0.23-0.27 \mathrm{mg} / \mathrm{g} \mathrm{FW}$ & [83] \\
\hline
\end{tabular}


Table 2. Cont.

\begin{tabular}{|c|c|c|c|c|c|}
\hline \multicolumn{6}{|c|}{ Vaccine Candidates } \\
\hline $\begin{array}{l}\text { Recombinant } \\
\text { Protein }\end{array}$ & Pathogen/Disease & Expression System & Transformation Method & Expression Level & Reference \\
\hline CO17-1AK & $\begin{array}{l}\text { Human colorectal } \\
\text { cancer }\end{array}$ & $\begin{array}{c}\text { Tobacco } \\
\text { (Nicotiana tabacum) }\end{array}$ & $\begin{array}{c}\text { Agrobacterium mediated } \\
\text { (Stable expression } \\
\text { /Nucleus) }\end{array}$ & $0.25 \mathrm{mg} / \mathrm{kg} \mathrm{FW}$ & [84] \\
\hline Palivizumab-N & $\begin{array}{c}\text { Respiratory } \\
\text { syncytial virus }\end{array}$ & $\begin{array}{c}\text { Tobacco } \\
\text { (Nicotiana benthamiana) }\end{array}$ & $\begin{array}{l}\text { Agrobacterium mediated } \\
\text { (Transient expression) }\end{array}$ & $180 \mathrm{mg} / \mathrm{kg}$ FW & [85] \\
\hline E559 & Rabies & $\begin{array}{c}\text { Tobacco } \\
\text { (Nicotiana tabacum) }\end{array}$ & $\begin{array}{c}\text { Agrobacterium mediated } \\
\text { (Stable expression } \\
\text { /Nucleus) }\end{array}$ & $\begin{array}{c}1.8 \mathrm{mg} / \mathrm{kg} \mathrm{FW} \\
(0.04 \% \text { of total } \\
\text { soluble protein })\end{array}$ & [86] \\
\hline pE16 & West Nile virus & $\begin{array}{c}\text { Tobacco } \\
\text { (Nicotiana benthamiana } \\
\Delta \mathrm{XF})\end{array}$ & $\begin{array}{l}\text { Agrobacterium mediated } \\
\text { (Transient expression) }\end{array}$ & $0.74 \mathrm{mg} / \mathrm{g}$ FW & [87] \\
\hline $\mathrm{pE} 16 \mathrm{scFv}-\mathrm{CH}$ & West Nile virus & $\begin{array}{c}\text { Tobacco } \\
\text { (Nicotiana benthamiana } \\
\Delta \mathrm{XF})\end{array}$ & $\begin{array}{l}\text { Agrobacterium mediated } \\
\text { (Transient expression) }\end{array}$ & $0.77 \mathrm{mg} / \mathrm{g}$ FW & [87] \\
\hline E60 & Dengue virus & $\begin{array}{c}\text { Tobacco } \\
\text { (Nicotiana benthamiana) }\end{array}$ & $\begin{array}{l}\text { Agrobacterium mediated } \\
\text { (Transient expression) }\end{array}$ & $120 \mu \mathrm{g} / \mathrm{g}$ FW & {$[88]$} \\
\hline $2 \mathrm{G} 12$ & HIV & Rice (Oryza sativa) & $\begin{array}{c}\text { Biolistic method (Stable } \\
\text { expression } \\
\text { /Nucleus) }\end{array}$ & $\begin{array}{l}46.4 \mu \mathrm{g} / \mathrm{g} \text { dry seed } \\
\text { weight }\end{array}$ & [89] \\
\hline $8 \mathrm{~B} 10$ and $5 \mathrm{~F} 10$ & Chikungunya virus & $\begin{array}{c}\text { Tobacco } \\
\text { (Nicotiana benthamiana) }\end{array}$ & $\begin{array}{l}\text { Agrobacterium mediated } \\
\text { (Transient expression) }\end{array}$ & $20-30 \mathrm{mg} / \mathrm{kg}$ FW & [71] \\
\hline SO57 & Rabies virus & $\begin{array}{c}\text { Tobacco } \\
\text { (Nicotiana tabacum) }\end{array}$ & $\begin{array}{l}\text { Agrobacterium mediated } \\
\text { (Transient expression) }\end{array}$ & $\begin{array}{c}0.014-0.019 \% \text { of } \\
\text { total soluble } \\
\text { protein }\end{array}$ & [90] \\
\hline cD5 & Enterovirus 71 & $\begin{array}{c}\text { Tobacco } \\
\text { (Nicotiana benthamiana) }\end{array}$ & $\begin{array}{l}\text { Agrobacterium mediated } \\
\text { (Transient expression) }\end{array}$ & $50 \mu \mathrm{g} / \mathrm{g}$ FW & [91] \\
\hline PD1 & Cancer & $\begin{array}{c}\text { Tobacco } \\
\text { (Nicotiana benthamiana) }\end{array}$ & $\begin{array}{l}\text { Agrobacterium mediated } \\
\text { (Transient expression) }\end{array}$ & $140 \mu \mathrm{g} / \mathrm{g} F W$ & [92] \\
\hline c2A10G6 & Zika virus & $\begin{array}{c}\text { Tobacco } \\
\text { (Nicotiana benthamiana) }\end{array}$ & $\begin{array}{l}\text { Agrobacterium mediated } \\
\text { (Transient expression) }\end{array}$ & $1.47 \mathrm{mg} / \mathrm{g} F W$ & [93] \\
\hline $6 \mathrm{D} 8$ & Ebola & $\begin{array}{c}\text { Tobacco } \\
\text { (Nicotiana benthamiana) }\end{array}$ & $\begin{array}{l}\text { Agrobacterium mediated } \\
\text { (Transient expression) }\end{array}$ & $1.21 \mathrm{mg} / \mathrm{g} \mathrm{FW}$ & [93] \\
\hline HSV8 & $\begin{array}{l}\text { Herpes simplex } \\
\text { virus }\end{array}$ & $\begin{array}{c}\text { Tobacco } \\
\text { (Nicotiana benthamiana) }\end{array}$ & $\begin{array}{l}\text { Agrobacterium mediated } \\
\text { (Transient expression) }\end{array}$ & $1.42 \mathrm{mg} / \mathrm{g} F W$ & [93] \\
\hline CHKV mab & Chikungunya virus & $\begin{array}{c}\text { Tobacco } \\
\text { (Nicotiana benthamiana) }\end{array}$ & $\begin{array}{l}\text { Agrobacterium mediated } \\
\text { (Transient expression) }\end{array}$ & $100 \mu \mathrm{g} / \mathrm{g} \mathrm{FW}$ & [94] \\
\hline
\end{tabular}

Table 3. Selected list of various non-pharmaceutical proteins produced in plants.

\begin{tabular}{ccccc}
\hline $\begin{array}{c}\text { Recombinant } \\
\text { Proteins }\end{array}$ & Expression System & $\begin{array}{c}\text { Transformation } \\
\text { Method }\end{array}$ & Expression Level & Reference \\
\hline $\begin{array}{c}\text { Human serum } \\
\text { albumin }\end{array}$ & $\begin{array}{c}\text { Potato } \\
\text { (Solanum tuberosum) }\end{array}$ & $\begin{array}{c}\text { Agrobacterium } \\
\text { mediated (Stable } \\
\text { expression/Nucleus) }\end{array}$ & $\begin{array}{c}0.25 \mu \mathrm{gg} / \mathrm{mg}(0.02 \% \\
\text { of total soluble } \\
\text { protein) }\end{array}$ & {$[95]$} \\
\hline Erythropoietin & $\begin{array}{c}\text { Tobacco } \\
\text { (Nicotiana tabacum) }\end{array}$ & $\begin{array}{c}\text { Agrobacterium } \\
\text { mediated (Stable } \\
\text { expression/Nucleus) }\end{array}$ & $\begin{array}{c}\text { 26 pg/mg total } \\
\text { protein }\end{array}$ & {$[96]$} \\
\hline R1-antitrypsin & Rice (Japonica rice) & $\begin{array}{c}\text { Biolistic method } \\
\text { (Stable } \\
\text { expression/Nucleus) }\end{array}$ & $\begin{array}{c}\text { 4.6-5.7 mg/g dry } \\
\text { cell }\end{array}$ & [97] \\
\hline Aprotinin & Corn & $\begin{array}{c}\text { Biolistic method } \\
\text { (Stable } \\
\text { expression/Nucleus) }\end{array}$ & $\begin{array}{c}0.069 \% \text { of total } \\
\text { extractable seed } \\
\text { protein }\end{array}$ & {$[98]$} \\
\hline
\end{tabular}


Table 3. Cont

\begin{tabular}{|c|c|c|c|c|}
\hline $\begin{array}{l}\text { Recombinant } \\
\text { Proteins }\end{array}$ & Expression System & $\begin{array}{c}\text { Transformation } \\
\text { Method }\end{array}$ & Expression Level & Reference \\
\hline $\begin{array}{c}\text { Human-secreted } \\
\text { alkaline } \\
\text { phosphatase }\end{array}$ & $\begin{array}{c}\text { Tobacco } \\
\text { (Nicotiana tabacum) }\end{array}$ & $\begin{array}{c}\text { Agrobacterium } \\
\text { mediated (Stable } \\
\text { expression/Nucleus) }\end{array}$ & $\begin{array}{c}1.1 \mu \mathrm{g} / \mathrm{g} \mathrm{FW}(3 \% \text { of } \\
\text { total soluble } \\
\text { protein })\end{array}$ & [99] \\
\hline Collagen & $\begin{array}{c}\text { Tobacco } \\
\text { (Nicotiana tabacum) }\end{array}$ & $\begin{array}{c}\text { Agrobacterium } \\
\text { mediated (Stable } \\
\text { expression/Nucleus) }\end{array}$ & $\begin{array}{c}0.03 \mathrm{~g} / \mathrm{kg} \\
\text { powdered plants }\end{array}$ & [100] \\
\hline $\begin{array}{c}\text { Human } \\
\text { somatotropin }(\mathrm{hST})\end{array}$ & Tobacco & $\begin{array}{c}\text { Biolistic method } \\
\text { (Stable } \\
\text { expression/Chloroplast) }\end{array}$ & $\begin{array}{c}>7 \% \text { of total } \\
\text { soluble protein }\end{array}$ & [101] \\
\hline $\begin{array}{c}\text { Bacillus } \\
\text { thuringiensis }(\mathrm{Bt}) \\
\text { cry2Aa2 }\end{array}$ & Tobacco & $\begin{array}{c}\text { Biolistic method } \\
\text { (Stable } \\
\text { expression/Chloroplast) }\end{array}$ & $\begin{array}{c}5 \mathrm{mg} / \mathrm{g} \mathrm{FW} \\
(45.3-46.1 \% \text { of total } \\
\text { soluble protein) }\end{array}$ & [102] \\
\hline $\begin{array}{l}\text { Human serum } \\
\text { albumin }\end{array}$ & $\begin{array}{c}\text { Tobacco } \\
\text { (Nicotiana tabacum) }\end{array}$ & $\begin{array}{l}\text { Biolistic method (Stable } \\
\text { expression/Chloroplast) }\end{array}$ & $\begin{array}{c}11.1 \% \text { of total } \\
\text { protein }\end{array}$ & [103] \\
\hline $\begin{array}{c}\text { Human epidermal } \\
\text { growth factor } \\
(\mathrm{hEGF})\end{array}$ & $\begin{array}{c}\text { Tobacco } \\
\text { (Nicotiana tabacum) }\end{array}$ & $\begin{array}{c}\text { Agrobacterium } \\
\text { mediated (Stable } \\
\text { expression/Nucleus) }\end{array}$ & $34.2 \mu \mathrm{g} / \mathrm{g} \mathrm{FW}$ & [104] \\
\hline $\begin{array}{l}\text { Human basic } \\
\text { fibroblast growth } \\
\text { factor (bFGF) }\end{array}$ & Soybean (Glycine max) & $\begin{array}{l}\text { Cotyledonary node } \\
\text { explant method (Stable } \\
\text { expression/Nucleus) }\end{array}$ & $\begin{array}{l}2.3 \% \text { of total } \\
\text { soluble protein }\end{array}$ & [105] \\
\hline $\begin{array}{l}\text { Type I interferon } \\
\quad(\text { IFN } \alpha 2 b)\end{array}$ & $\begin{array}{c}\text { Tobacco } \\
\text { (Nicotiana tabacum) }\end{array}$ & $\begin{array}{l}\text { Biolistic method (Stable } \\
\text { expression/Chloroplast) }\end{array}$ & $\begin{array}{c}3 \mathrm{mg} / \mathrm{g} \mathrm{FW}(20 \% \text { of } \\
\text { total soluble } \\
\text { protein })\end{array}$ & [106] \\
\hline $\begin{array}{l}\text { Human growth } \\
\text { hormone (hGH) }\end{array}$ & Rice (Oryza sativa) & $\begin{array}{c}\text { Biolistic method } \\
\text { (Stable } \\
\text { expression/Nucleus) }\end{array}$ & $\begin{array}{l}57 \mathrm{mg} / \mathrm{L} \text { culture } \\
\text { medium }\end{array}$ & [107] \\
\hline PlyGBS lysin & $\begin{array}{c}\text { Tobacco } \\
\text { (Nicotiana tabacum) }\end{array}$ & $\begin{array}{l}\text { Biolistic method (Stable } \\
\text { expression/Chloroplast) }\end{array}$ & $\begin{array}{l}>70 \% \text { of the total } \\
\text { soluble protein }\end{array}$ & [108] \\
\hline $\begin{array}{l}\text { Human growth } \\
\text { hormone (hGH) }\end{array}$ & Tobacco BY-2 cells & $\begin{array}{c}\text { Agrobacterium } \\
\text { mediated (Stable } \\
\text { expression/Nucleus) }\end{array}$ & $\begin{array}{l}35 \mathrm{mg} / \mathrm{L} \text { culture } \\
\text { medium }(2-4 \% \text { of } \\
\text { total soluble } \\
\text { protein) }\end{array}$ & [109] \\
\hline $\begin{array}{l}\text { Human basic } \\
\text { fibroblast growth } \\
\text { factor (bFGF) }\end{array}$ & Rice (Oryza sativa) & $\begin{array}{c}\text { Agrobacterium } \\
\text { mediated (Stable } \\
\text { expression/Nucleus) }\end{array}$ & $185.66 \mathrm{mg} / \mathrm{kg}$ & [110] \\
\hline Lumbrokinase & $\begin{array}{c}\text { Sunflower } \\
\text { (Helianthus annuus L.) }\end{array}$ & $\begin{array}{c}\text { Agrobacterium } \\
\text { mediated (Stable } \\
\text { expression/Nucleus) }\end{array}$ & $5.1 \mathrm{~g} / \mathrm{kg}$ seeds & [111] \\
\hline $\begin{array}{l}\text { Human acidic } \\
\text { fibroblast growth } \\
\text { factor } 1 \text { (FGF-1) }\end{array}$ & Salvia miltiorrhiza & $\begin{array}{c}\text { Agrobacterium } \\
\text { mediated (Stable } \\
\text { expression/Nucleus) }\end{array}$ & 272 ng/g FW & [112] \\
\hline $\begin{array}{c}\text { Glucocerebrosidase } \\
\text { (GCase) }\end{array}$ & $\begin{array}{c}\text { Tobacco } \\
\text { (Nicotiana benthamiana) }\end{array}$ & $\begin{array}{c}\text { Agrobacterium } \\
\text { mediated (Stable } \\
\text { expression/Nucleus) }\end{array}$ & $\begin{array}{c}68 \mu \mathrm{g} / \mathrm{g} \mathrm{FW} \\
(1.45 \% \text { of total } \\
\text { soluble protein) }\end{array}$ & [113] \\
\hline $\begin{array}{l}\text { Human acid alpha } \\
\text { glucosidase }\end{array}$ & $\begin{array}{c}\text { Tobacco } \\
\text { (Nicotiana tabacum) }\end{array}$ & $\begin{array}{l}\text { Biolistic method (Stable } \\
\text { expression/Chloroplast) }\end{array}$ & $6.38 \mu \mathrm{g} / \mathrm{g}$ FW & [114] \\
\hline $\begin{array}{l}\text { Human basic } \\
\text { fibroblast growth } \\
\text { factor }(\mathrm{bFGF})\end{array}$ & $\begin{array}{c}\text { Tobacco } \\
\text { (Nicotiana tabacum) }\end{array}$ & $\begin{array}{l}\text { Biolistic method (Stable } \\
\text { expression/Chloroplast) }\end{array}$ & $\begin{array}{l}0.1 \% \text { of total } \\
\text { soluble protein }\end{array}$ & [115] \\
\hline
\end{tabular}


Table 3. Cont

\begin{tabular}{|c|c|c|c|c|}
\hline $\begin{array}{l}\text { Recombinant } \\
\text { Proteins }\end{array}$ & Expression System & $\begin{array}{c}\text { Transformation } \\
\text { Method }\end{array}$ & Expression Level & Reference \\
\hline Endo- $\beta-1,4$-xylanase & $\begin{array}{c}\text { Tobacco } \\
\text { (Nicotiana tabacum) }\end{array}$ & $\begin{array}{l}\text { Biolistic method (Stable } \\
\text { expression/Chloroplast) }\end{array}$ & $\begin{array}{c}35.7 \% \text { of total } \\
\text { soluble protein }\end{array}$ & [116] \\
\hline$\beta$-Glucosidase & $\begin{array}{c}\text { Tobacco } \\
\text { (Nicotiana tabacum) }\end{array}$ & $\begin{array}{l}\text { Biolistic method (Stable } \\
\text { expression/Chloroplast) }\end{array}$ & $\begin{array}{l}>75 \% \text { of total } \\
\text { soluble protein }\end{array}$ & [116] \\
\hline Osteopontin (OPN) & $\begin{array}{c}\text { Tobacco } \\
\text { (Nicotiana benthamiana) }\end{array}$ & $\begin{array}{c}\text { Agrobacterium } \\
\text { mediated } \\
\text { (Transient expression) }\end{array}$ & 100 ng/g FW & [117] \\
\hline $\begin{array}{c}\text { Dentin matrix } \\
\text { protein-1 (DMP1) }\end{array}$ & $\begin{array}{c}\text { Tobacco } \\
\text { (Nicotiana benthamiana) }\end{array}$ & $\begin{array}{c}\text { Agrobacterium } \\
\text { mediated } \\
\text { (Transient expression) }\end{array}$ & $0.3 \mu \mathrm{g} / \mathrm{g}$ FW & [118] \\
\hline
\end{tabular}

\section{Strategies Used for Recombinant Protein Production in Plants}

The expression methods used for the recombinant protein production in plants can be either stable or transient expression. PMF relies on following approaches for the expression of vaccine candidates, i.e., stable nuclear transformation, stable chloroplast transformation, or transient expression, by using plant viral vectors and stable transformation of hydroponically grown plants in which recombinant proteins are recovered from the medium [119] (Figure 1).

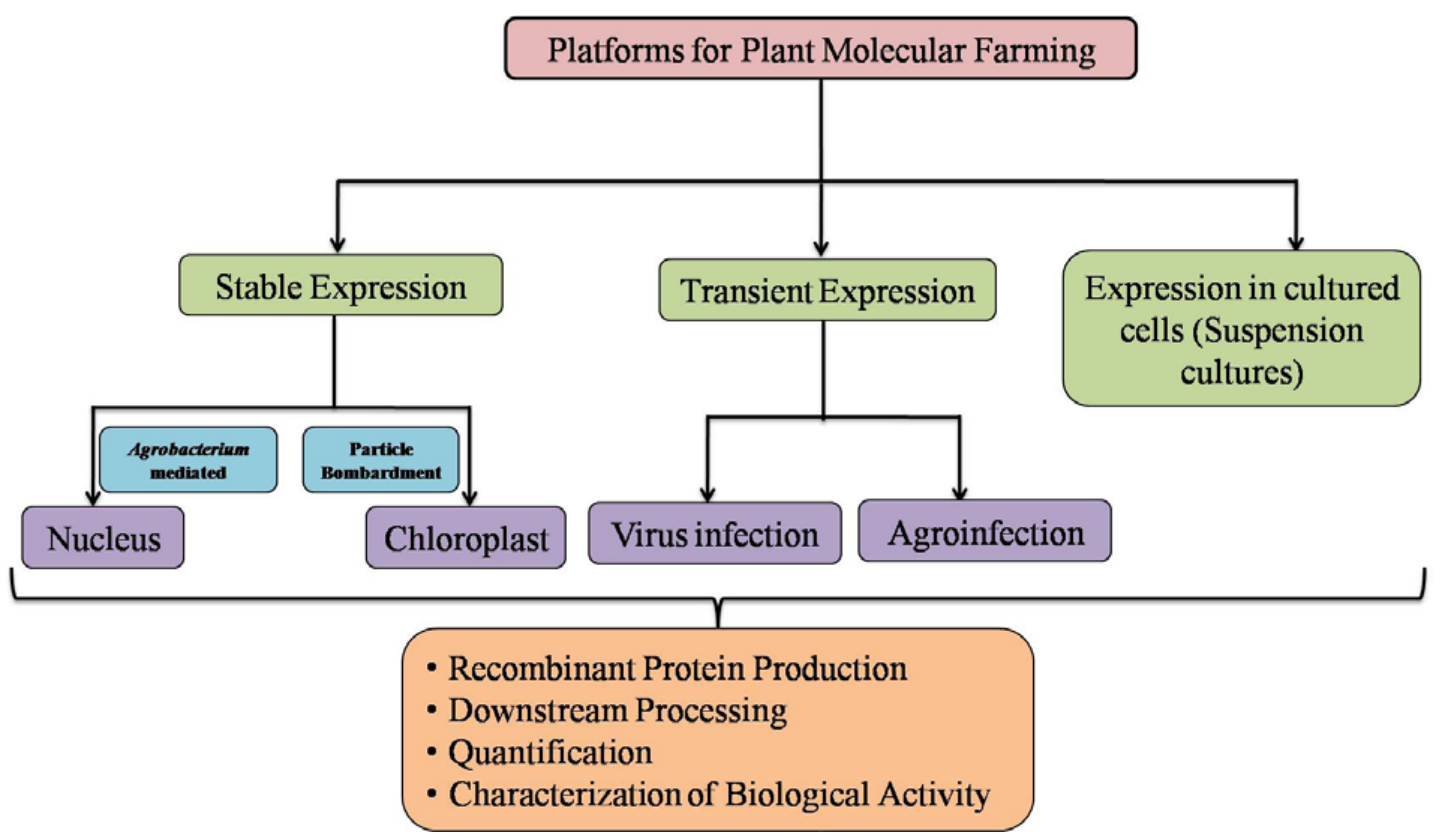

Figure 1. Overview of plant transformation approaches employed for the production of recombinant pharmaceutical and non-pharmaceutical proteins in plants.

Stable nuclear transformation is the traditional strategy of genetic manipulation in plants for recombinant protein production. The transgene in the plant expression vector can be introduced into the in vitro grown plantlets either with Agrobacterium tumefaciens-mediated transformation or particle bombardment, and stable transgenic lines can be developed. The best transgenic line for protein production will be subsequently screened from the pool of transgenic lines. By this method, recombinant proteins can be produced in successive generations, as the transgene has been stably integrated into the plant genome. The model plants such as Arabidopsis thaliana and tobacco were more commonly used during the early stages of genetic transformation to develop stable transformants [79]. 
Stable transformation in plants requires substantial time and is a labor-intensive process, and the protein expression is insufficient to meet the industrial-level protein production. However, the antigen expression in stable transgenic line could be used for developing oral vaccines that could reduce the cost associated with protein purification $[120,121]$.

Alternatively, transient expression based on agroinfiltration or virus-based vectors have been developed to complement transgenic plants that offer rapid and high-level protein expression within a few days. The drawbacks and challenges associated with stable expression, such as insufficient protein expression, time, and consistency, have been overcome by the development of novel strategies involving deconstructed viral vector systems such as MagnICON ${ }^{\circledR}$ technology, geminiviral, and pEAQ, which allows rapid accumulation of recombinant proteins in a short time [12]. Hence, it is considered as a suitable convenient platform, especially for the production of vaccine antigens or monoclonal antibodies against infectious diseases (Figure 2). Gleba et al. (2007) summarized the application of plant viral vectors for the transient expression of heterologous proteins in plants [122]. Plant transient expression holds tremendous potential to produce rapid-response proteins, emergency vaccines, or biologics, which was impressively shown during the Ebola outbreak in 2014. Mapp Biopharmaceutical Inc., USA produced an experimental drug ZMapp, an anti-Ebola antibody cocktail of three chimeric monoclonal antibodies manufactured in tobacco plants (Nicotiana benthamiana) to treat humans during the recent Ebola outbreak [123]. During a pandemic situation, in order to cope with a rapidly spreading infectious disease, production methods should meet the demand for production targets of strategic vaccines to control the disease. One of the recent examples is the pandemic, corona virus disease (COVID-19). The virus has spread rapidly, and millions of people have been affected across 6 continents in few months, posing a constant threat to global health. This infection has created a massive demand for diagnostic reagents, vaccines, and therapeutic development. Given the speed advantages, and proven viability of the plant production platform, the transient expression system in particular could be employed to produce recombinant proteins at high levels to meet the sudden demand for production of viral antigens or antiviral proteins that could be used as research reagents, emergency vaccines (SARS-CoV-2 subunit and virus-like particle vaccines), or other biopharmaceuticals to fight against COVID-19 [25,124]. The neutralizing monoclonal antibodies against SARS-CoV-2 could also be produced in plants with minimal investment, which could be used for passive immunotherapy [125]. Recently, Medicago (Quebec, Canada), Kentucky BioProcessing (Owensboro, KT, USA), and iBio (Bryan, TX, USA) joined the global race for developing potential plant-based vaccines for COVID-19 [126]. By using the transient expression platform, recombinant protein production in plants could be scaled up rapidly, and milligram quantities of proteins could be produced in a timeframe of less than 4 weeks after receiving the corresponding gene construct $[5,59,127]$.

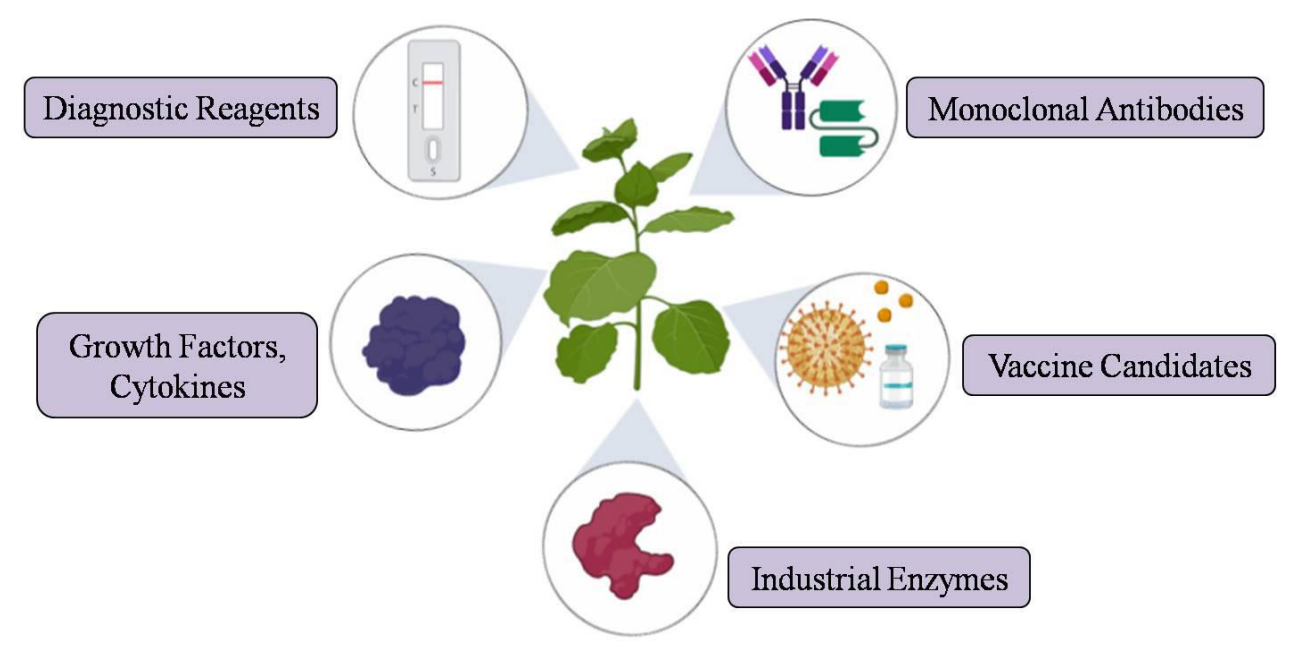

Figure 2. Schematic representation depicting the application of transient expression system for the production of various recombinant proteins. 
Alternately, chloroplast expression focuses on expressing the transgenes in chloroplast by the precise insertion of foreign DNA by homologous recombination into the chloroplast genome. Much progress has been made in chloroplast engineering in recent years. The transformation of the chloroplast genome has many advantages over nuclear transformation which includes higher protein production, lack of gene silencing and position effect, polycistronic mRNA expression, and prevention of transmission of foreign DNA through pollen by uniparental plastid gene inheritance (maternal inheritance) in crop plants [128-131].

Similar to bacterial and mammalian cells, heterologous protein production can be achieved by using individual suspension of plant cells rather than whole plants. The cell suspension derived from undifferentiated callus grown in liquid medium can be scaled up in bioreactors for large-scale protein production under an aseptic environment. The first USDA-approved poultry vaccine and the first FDA-approved recombinant plant-produced pharmaceutical protein "Elelyso" were produced in tobacco and carrot cell suspension cultures, respectively, which proved the importance and competitiveness of plant suspension culture in high-value protein production in the biopharmaceutical industry [121,132-134]. Hairy root cultures are also being explored as an alternative recombinant protein production system due to their ease in protein recovery and low costs. The recombinant proteins are secreted from the transgenic plant roots into the culture medium viz., rhizosecretion; hence, this allows continuous protein production and recovery from the culture medium without the requirement of cell lysis during extraction. Moreover, recombinant proteins produced from root cultures attribute to the improved protein quality and quantity without complex downstream processing that could eventually reduce production costs as well [135]. A recent review on the applications of hairy root cultures for protein production has been extensively discussed by Gutierrez-Valdes et al. (2020) [136].

\section{Perspectives}

Although plants are attractive with several unique advantages, they are unable to compete with the existing microbial and mammalian systems, as both are well established and characterized, especially in terms of GMP manufacturing and regulatory approval in an industrial setting. Even after many years of research, which has shown the proof-of-concept of expressing many therapeutic proteins in plants, the process of producing therapeutic proteins from the lab bench to commercialization is slow. Hence, in order to move forward, the commercial potential and economic sustainability of technology needs to be exploited by developing veterinary vaccines, non-pharmaceutical diagnostic, cosmetic products, and industrial enzymes in plants, as they have a low regulatory burden compared to therapeutic proteins [2,9]. This technology can also be employed to reproduce rapid response vaccines or diagnostic reagents against emerging infections. For the past few years, extensive research has been carried out to combat the several emerging diseases including Zika, chikungunya, Nipah, SARS-CoV, MERS-CoV, and more recently SARS-CoV-2. Even though several efforts have been made for many years to develop effective vaccine candidates for many of those emerging and zoonotic diseases, still, there are no vaccine candidates or therapeutic measures available commercially. Even if a successful vaccine or drug developed against such diseases, it is unlikely that it would have a significant impact on developing and under-developed countries, due to the high cost associated with it, and scalability concern. In such a scenario, a plant-derived vaccine or diagnostic reagent would be a feasible approach to rapidly respond to the demand and need for recombinant proteins. However, harnessing the full potential of this plant molecular farming technology for cost-effective vaccines or drug development will be evident in the upcoming years.

\section{Conclusions}

Plants have both economic and technical advantages over conventional expression systems for the production of pharmaceutical and non-pharmaceutical products. The different PMF technologies such as nuclear, chloroplast expression, viral transfection, and transient expression systems have their unique features, enabling them to address a production of diversified product "targets" with less 
production constraints in a short time. Many scientific and technical challenges associated with the plant platform were met in recent years. However, the regulatory burden associated with therapeutic protein production is a major barrier that hinders the widespread acceptance of the plant system. Considering the low costs and greater scalability of plant production systems, the commercialization of non-pharmaceutical proteins is straightforward and faster due to lower regulatory challenges. Hence, the universal acceptance of the technology will be strongly influenced by the regulatory framework and restrictions applied to plant-derived products worldwide. The demand for industrially or pharmaceutically useful recombinant proteins, together with demonstrated production capability and economic feasibility of the plant system, suggests a bright future for the plant-made biologics.

Author Contributions: Conceptualization, B.S. and W.P.; literature review, B.S. and C.J.I.B.; writing-original draft preparation, B.S.; writing-review and editing, B.S., C.J.I.B. and W.P.; supervision, W.P.; funding acquisition, W.P. All authors have read and agreed to the published version of the manuscript.

Funding: This research received no external funding.

Acknowledgments: The authors would like to acknowledge Scholarship Program for Asean Countries (C.J.I.B.) and Second Century Fund-C2F (B.S.), Chulalongkorn University for financial support.

Conflicts of Interest: The authors declare no conflict of interest.

\begin{tabular}{ll}
\multicolumn{2}{l}{ Abbreviations } \\
cGMP & Current good manufacturing practice \\
COVID-19 & Coronavirus disease \\
FW & Fresh weight \\
mAb & Monoclonal antibody \\
MERS-CoV & Middle East respiratory syndrome coronavirus \\
PMF & Plant molecular farming \\
PTM & Post-translational modification \\
SARS-CoV & Severe acute respiratory syndrome coronavirus \\
SARS-CoV-2 & Severe acute respiratory syndrome coronavirus 2
\end{tabular}

\section{References}

1. Burnett, M.J.B.; Burnett, A.C. Therapeutic recombinant protein production in plants: Challenges and opportunities. Plants People Planet 2020, 2, 121-132. [CrossRef]

2. Schillberg, S.; Raven, N.; Spiegel, H.; Rasche, S.; Buntru, M. Critical analysis of the commercial potential of plants for the production of recombinant proteins. Front. Plant Sci. 2019, 10, 720. [CrossRef] [PubMed]

3. Vieira Gomes, A.M.; Souza Carmo, T.; Silva Carvalho, L.; Mendonca Bahia, F.; Parachin, N.S. Comparison of yeasts as hosts for recombinant protein production. Microorganisms 2018, 6, 38. [CrossRef]

4. Lalonde, M.E.; Durocher, Y. Therapeutic glycoprotein production in mammalian cells. J. Biotechnol. 2017, 251, 128-140. [CrossRef]

5. Sainsbury, F.; Lomonossoff, G.P. Transient expressions of synthetic biology in plants. Curr. Opin. Plant Biol. 2014, 19, 1-7. [CrossRef]

6. Shanmugaraj, B.; Ramalingam, S. Plant expression platform for the production of recombinant pharmaceutical proteins. Austin J. Biotechnol. Bioeng. 2014, 1, 4.

7. Hiatt, A.; Cafferkey, R.; Bowdish, K. Production of antibodies in transgenic plants. Nature 1989, 342, 76-78. [CrossRef] [PubMed]

8. Fox, J.L. First plant-made biologic approved. Nat. Biotechnol. 2012, 30, 472. [CrossRef]

9. Tschofen, M.; Knopp, D.; Hood, E.; Stöger, E. Plant molecular farming: Much more than medicines. Annu. Rev. Anal. Chem. 2016, 9, 271-294. [CrossRef]

10. Daniell, H.; Singh, N.D.; Mason, H.; Streatfield, S.J. Plant-made vaccine antigens and biopharmaceuticals. Trends Plant Sci. 2009, 14, 669-679. [CrossRef]

11. Lomonossoff, G.P.; D’Aoust, M.A. Plant-produced biopharmaceuticals: A case of technical developments driving clinical deployment. Science 2016, 353, 1237-1240. [CrossRef] [PubMed] 
12. Park, K.Y.; Wi, S.J. Potential of plants to produce recombinant protein products. J. Plant Biol. 2016, 59, 559-568. [CrossRef] [PubMed]

13. Topp, E.; Irwin, R.; McAllister, T.; Lessard, M.; Joensuu, J.J.; Kolotilin, I.; Conrad, U.; Stoger, E.; Mor, T.; Warzecha, H.; et al. The case for plant-made veterinary immunotherapeutics. Biotechnol. Adv. 2016, 34, 597-604. [CrossRef] [PubMed]

14. Sohrab, S.S.; Suhail, M.; Kamal, M.A.; Husen, A.; Azhar, E.I. Recent development and future prospects of plant-based vaccines. Curr. Drug Metab. 2017, 18, 831-841. [CrossRef] [PubMed]

15. Wong-Arce, A.; Gonzalez-Ortega, O.; Rosales-Mendoza, S. Plant-made vaccines in the fight against cancer. Trends Biotechnol. 2017, 35, 241-256. [CrossRef] [PubMed]

16. Taunt, H.N.; Stoffels, L.; Purton, S. Green biologics: The algal chloroplast as a platform for making biopharmaceuticals. Bioengineered 2018, 9, 48-54. [CrossRef]

17. Donini, M.; Marusic, C. Current state-of-the-art in plant-based antibody production systems. Biotechnol. Lett. 2019, 41, 335-346. [CrossRef]

18. Rybicki, E.P. Plant molecular farming of virus-like nanoparticles as vaccines and reagents. Wiley Interdiscip. Rev. Nanomed. Nanobiotechnol. 2020, 12, e1587. [CrossRef]

19. Chen, Q.; Davis, K.R. The potential of plants as a system for the development and production of human biologics. F1000Research 2016, 5. [CrossRef]

20. Sahdev, S.; Khattar, S.K.; Saini, K.S. Production of active eukaryotic proteins through bacterial expression systems: A review of the existing biotechnology strategies. Mol. Cell. Biochem. 2008, 307, 249-264. [CrossRef]

21. Strasser, R.; Stadlmann, J.; Schahs, M.; Stiegler, G.; Quendler, H.; Mach, L.; Glossl, J.; Weterings, K.; Pabst, M.; Steinkellner, H. Generation of glyco-engineered Nicotiana benthamiana for the production of monoclonal antibodies with a homogeneous human-like N-glycan structure. Plant Biotechnol. J. 2008, 6, 392-402. [CrossRef] [PubMed]

22. Montero-Morales, L.; Steinkellner, H. Advanced plant-based glycan engineering. Front. Bioeng. Biotechnol. 2018, 6, 81. [CrossRef] [PubMed]

23. Paul, M.; Ma, J.K. Plant-made pharmaceuticals: Leading products and production platforms. Biotechnol. Appl. Biochem. 2011, 58, 58-67. [CrossRef]

24. Yao, J.; Weng, Y.; Dickey, A.; Wang, K.Y. Plants as factories for human pharmaceuticals: Applications and challenges. Int. J. Mol. Sci. 2015, 16, 28549-28565. [CrossRef] [PubMed]

25. Shanmugaraj, B.; Malla, A.; Phoolcharoen, W. Emergence of novel coronavirus 2019-nCoV: Need for rapid vaccine and biologics development. Pathogens 2020, 9, 148. [CrossRef]

26. Zhou, J.Y.; Cheng, L.Q.; Zheng, X.J.; Wu, J.X.; Shang, S.B.; Wang, J.Y.; Chen, J.G. Generation of the transgenic potato expressing full-length spike protein of infectious bronchitis virus. J. Biotechnol. 2004, 111, 121-130. [CrossRef]

27. Daniell, H.; Rai, V.; Xiao, Y. Cold chain and virus-free oral polio booster vaccine made in lettuce chloroplasts confers protection against all three poliovirus serotypes. Plant Biotechnol. J. 2019, 17, 1357-1368. [CrossRef]

28. Marsian, J.; Fox, H.; Bahar, M.W.; Kotecha, A.; Fry, E.E.; Stuart, D.I.; Macadam, A.J.; Rowlands, D.J.; Lomonossoff, G.P. Plant-made polio type 3 stabilized VLPs-a candidate synthetic polio vaccine. Nat. Commun. 2017, 8, 245. [CrossRef]

29. Diamos, A.G.; Mason, H.S. High-level expression and enrichment of norovirus virus-like particles in plants using modified geminiviral vectors. Protein Expr. Purif. 2018, 151, 86-92. [CrossRef]

30. Veerapen, V.P.; van Zyl, A.R.; Wigdorovitz, A.; Rybicki, E.P.; Meyers, A.E. Novel expression of immunogenic foot-and-mouth disease virus-like particles in Nicotiana benthamiana. Virus Res. 2018, 244, 213-217. [CrossRef]

31. Smith, T.; O'Kennedy, M.M.; Wandrag, D.B.R.; Adeyemi, M.; Abolnik, C. Efficacy of a plant-produced virus-like particle vaccine in chickens challenged with Influenza A H6N2 virus. Plant Biotechnol. J. 2020, 18, 502-512. [CrossRef]

32. Scotti, N.; Rybicki, E.P. Virus-like particles produced in plants as potential vaccines. Expert Rev. Vaccines 2013, 12, 211-224. [CrossRef] [PubMed]

33. Rybicki, E.P. Plant-based vaccines against viruses. Virol. J. 2014, 11, 205. [CrossRef] [PubMed]

34. Hood, E.E.; Witcher, D.R.; Maddock, S.; Meyer, T.; Baszczynski, C.; Bailey, M.; Flynn, P.; Register, J.; Marshall, L.; Bond, D.; et al. Commercial production of avidin from transgenic maize: Characterization of transformant, production, processing, extraction and purification. Mol. Breed. 1997, 3, 291-306. [CrossRef] 
35. Witcher, D.R.; Hood, E.E.; Peterson, D.; Bailey, M.; Bond, D.; Kusnadi, A.; Evangelista, R.; Nikolov, Z.; Wooge, C.; Mehigh, R.; et al. Commercial production of $\beta$-glucuronidase (GUS): A model system for the production of proteins in plants. Mol. Breed. 1998, 4, 301-312. [CrossRef]

36. Woodard, S.L.; Mayor, J.M.; Bailey, M.R.; Barker, D.K.; Love, R.T.; Lane, J.R.; Delaney, D.E.; McComas-Wagner, J.M.; Mallubhotla, H.D.; Hood, E.E.; et al. Maize (Zea mays)-derived bovine trypsin: Characterization of the first large-scale, commercial protein product from transgenic plants. Biotechnol. Appl. Biochem. 2003, 38, 123-130. [CrossRef]

37. Ma, J.K.-C.; Drossard, J.; Lewis, D.; Altmann, F.; Boyle, J.; Christou, P.; Cole, T.; Dale, P.; van Dolleweerd, C.J.; Isitt, V.; et al. Regulatory approval and a first-in-human phase I clinical trial of a monoclonal antibody produced in transgenic tobacco plants. Plant Biotechnol. J. 2015, 13, 1106-1120. [CrossRef]

38. Mason, H.S.; Lam, D.M.; Arntzen, C.J. Expression of hepatitis B surface antigen in transgenic plants. Proc. Natl. Acad. Sci. USA 1992, 89, 11745. [CrossRef]

39. Castanon, S.; Marin, M.S.; Martin-Alonso, J.M.; Boga, J.A.; Casais, R.; Humara, J.M.; Ordas, R.J.; Parra, F. Immunization with potato plants expressing VP60 protein protects against rabbit hemorrhagic disease virus. J. Virol. 1999, 73, 4452-4455. [CrossRef]

40. Tuboly, T.; Yu, W.; Bailey, A.; Degrandis, S.; Du, S.; Erickson, L.; Nagy, E. Immunogenicity of porcine transmissible gastroenteritis virus spike protein expressed in plants. Vaccine 2000, 18, 2023-2028. [CrossRef]

41. Khandelwal, A.; Lakshmi Sita, G.; Shaila, M.S. Oral immunization of cattle with hemagglutinin protein of rinderpest virus expressed in transgenic peanut induces specific immune responses. Vaccine 2003, 21, 3282-3289. [CrossRef]

42. Pérez Filgueira, D.M.; Zamorano, P.I.; Domínguez, M.G.; Taboga, O.; Del Médico Zajac, M.P.; Puntel, M.; Romera, S.A.; Morris, T.J.; Borca, M.V.; Sadir, A.M. Bovine herpes virus gD protein produced in plants using a recombinant tobacco mosaic virus (TMV) vector possesses authentic antigenicity. Vaccine 2003, 21, 4201-4209. [CrossRef]

43. Varsani, A.; Williamson, A.L.; Rose, R.C.; Jaffer, M.; Rybicki, E.P. Expression of Human papillomavirus type 16 major capsid protein in transgenic Nicotiana tabacum cv. Xanthi. Arch. Virol. 2003, 148, 1771-1786. [CrossRef]

44. Lamphear, B.J.; Jilka, J.M.; Kesl, L.; Welter, M.; Howard, J.A.; Streatfield, S.J. A corn-based delivery system for animal vaccines: An oral transmissible gastroenteritis virus vaccine boosts lactogenic immunity in swine. Vaccine 2004, 22, 2420-2424. [CrossRef]

45. Koya, V.; Moayeri, M.; Leppla, S.H.; Daniell, H. Plant-based vaccine: Mice immunized with chloroplast-derived anthrax protective antigen survive anthrax lethal toxin challenge. Infect. Immun. 2005, 73, 8266-8274. [CrossRef] [PubMed]

46. Thanavala, Y.; Mahoney, M.; Pal, S.; Scott, A.; Richter, L.; Natarajan, N.; Goodwin, P.; Arntzen, C.J.; Mason, H.S. Immunogenicity in humans of an edible vaccine for hepatitis B. Proc. Natl. Acad. Sci. USA 2005, 102, 3378-3382. [CrossRef] [PubMed]

47. Guerrero-Andrade, O.; Loza-Rubio, E.; Olivera-Flores, T.; Fehervari-Bone, T.; Gomez-Lim, M.A. Expression of the Newcastle disease virus fusion protein in transgenic maize and immunological studies. Transgenic Res. 2006, 15, 455-463. [CrossRef]

48. Joensuu, J.J.; Verdonck, F.; Ehrstrom, A.; Peltola, M.; Siljander-Rasi, H.; Nuutila, A.M.; Oksman-Caldentey, K.M.; Teeri, T.H.; Cox, E.; Goddeeris, B.M.; et al. F4 (K88) fimbrial adhesin FaeG expressed in alfalfa reduces F4+ enterotoxigenic Escherichia coli excretion in weaned piglets. Vaccine 2006, 24, 2387-2394. [CrossRef]

49. Kohl, T.; Hitzeroth, I.I.; Stewart, D.; Varsani, A.; Govan, V.A.; Christensen, N.D.; Williamson, A.L.; Rybicki, E.P. Plant-produced cottontail rabbit papillomavirus L1 protein protects against tumor challenge: A proof-of-concept study. Clin. Vaccine Immunol. 2006, 13, 845-853. [CrossRef]

50. Wu, J.; Yu, L.; Li, L.; Hu, J.; Zhou, J.; Zhou, X. Oral immunization with transgenic rice seeds expressing VP2 protein of infectious bursal disease virus induces protective immune responses in chickens. Plant Biotechnol. J. 2007, 5, 570-578. [CrossRef]

51. Huang, Z.; LePore, K.; Elkin, G.; Thanavala, Y.; Mason, H.S. High-yield rapid production of hepatitis B surface antigen in plant leaf by a viral expression system. Plant Biotechnol. J. 2008, 6, 202-209. [CrossRef] 
52. D'Aoust, M.-A.; Lavoie, P.-O.; Couture, M.M.-J.; Trépanier, S.; Guay, J.-M.; Dargis, M.; Mongrand, S.; Landry, N.; Ward, B.J.; Vézina, L.-P. Influenza virus-like particles produced by transient expression in Nicotiana benthamiana induce a protective immune response against a lethal viral challenge in mice. Plant Biotechnol. J. 2008, 6, 930-940. [CrossRef] [PubMed]

53. Rosales-Mendoza, S.; Soria-Guerra, R.E.; Lopez-Revilla, R.; Moreno-Fierros, L.; Alpuche-Solis, A.G. Ingestion of transgenic carrots expressing the Escherichia coli heat-labile enterotoxin B subunit protects mice against cholera toxin challenge. Plant Cell Rep. 2008, 27, 79-84. [CrossRef] [PubMed]

54. Santi, L.; Batchelor, L.; Huang, Z.; Hjelm, B.; Kilbourne, J.; Arntzen, C.J.; Chen, Q.; Mason, H.S. An efficient plant viral expression system generating orally immunogenic Norwalk virus-like particles. Vaccine 2008, 26, 1846-1854. [CrossRef] [PubMed]

55. Wang, D.M.; Zhu, J.B.; Peng, M.; Zhou, P. Induction of a protective antibody response to FMDV in mice following oral immunization with transgenic Stylosanthes spp. as a feedstuff additive. Transgenic Res. 2008, 17, 1163-1170. [CrossRef] [PubMed]

56. Scotti, N.; Alagna, F.; Ferraiolo, E.; Formisano, G.; Sannino, L.; Buonaguro, L.; De Stradis, A.; Vitale, A.; Monti, L.; Grillo, S.; et al. High-level expression of the HIV-1 Pr55gag polyprotein in transgenic tobacco chloroplasts. Planta 2009, 229, 1109-1122. [CrossRef] [PubMed]

57. Wang, Y.; Deng, H.; Zhang, X.; Xiao, H.; Jiang, Y.; Song, Y.; Fang, L.; Xiao, S.; Zhen, Y.; Chen, H. Generation and immunogenicity of Japanese encephalitis virus envelope protein expressed in transgenic rice. Biochem. Biophys. Res. Commun. 2009, 380, 292-297. [CrossRef]

58. Kalthoff, D.; Giritch, A.; Geisler, K.; Bettmann, U.; Klimyuk, V.; Hehnen, H.R.; Gleba, Y.; Beer, M. Immunization with plant-expressed hemagglutinin protects chickens from lethal highly pathogenic avian influenza virus H5N1 challenge infection. J. Virol. 2010, 84, 12002-12010. [CrossRef] [PubMed]

59. Shoji, Y.; Farrance, C.E.; Bautista, J.; Bi, H.; Musiychuk, K.; Horsey, A.; Park, H.; Jaje, J.; Green, B.J.; Shamloul, M.; et al. A plant-based system for rapid production of influenza vaccine antigens. Influenza Other Respir. Viruses 2012, 6, 204-210. [CrossRef]

60. Kanagarajan, S.; Tolf, C.; Lundgren, A.; Waldenstrom, J.; Brodelius, P.E. Transient expression of hemagglutinin antigen from low pathogenic avian influenza A (H7N7) in Nicotiana benthamiana. PLoS ONE 2012, 7, e33010. [CrossRef]

61. Gómez, E.; Lucero, M.S.; Chimeno Zoth, S.; Carballeda, J.M.; Gravisaco, M.J.; Berinstein, A. Transient expression of VP2 in Nicotiana benthamiana and its use as a plant-based vaccine against Infectious Bursal Disease Virus. Vaccine 2013, 31, 2623-2627. [CrossRef] [PubMed]

62. Perez Aguirreburualde, M.S.; Gomez, M.C.; Ostachuk, A.; Wolman, F.; Albanesi, G.; Pecora, A.; Odeon, A.; Ardila, F.; Escribano, J.M.; Dus Santos, M.J.; et al. Efficacy of a BVDV subunit vaccine produced in alfalfa transgenic plants. Vet. Immunol. Immunopathol. 2013, 151, 315-324. [CrossRef] [PubMed]

63. Thuenemann, E.C.; Meyers, A.E.; Verwey, J.; Rybicki, E.P.; Lomonossoff, G.P. A method for rapid production of heteromultimeric protein complexes in plants: Assembly of protective bluetongue virus-like particles. Plant Biotechnol. J. 2013, 11, 839-846. [CrossRef] [PubMed]

64. Mathew, L.G.; Herbst-Kralovetz, M.M.; Mason, H.S. Norovirus Narita 104 virus-like particles expressed in Nicotiana benthamiana induce serum and mucosal immune responses. Biomed. Res. Int. 2014, 2014, 807539. [CrossRef]

65. Piron, R.; De Koker, S.; De Paepe, A.; Goossens, J.; Grooten, J.; Nauwynck, H.; Depicker, A. Boosting in planta production of antigens derived from the porcine reproductive and respiratory syndrome virus (PRRSV) and subsequent evaluation of their immunogenicity. PLoS ONE 2014, 9, e91386. [CrossRef]

66. Firsov, A.; Tarasenko, I.; Mitiouchkina, T.; Ismailova, N.; Shaloiko, L.; Vainstein, A.; Dolgov, S. High-yield expression of M2e peptide of Avian Influenza virus H5N1 in transgenic duckweed plants. Mol. Biotechnol. 2015, 57, 653-661. [CrossRef]

67. Mbewana, S.; Mortimer, E.; Pera, F.F.; Hitzeroth, I.I.; Rybicki, E.P. Production of H5N1 influenza virus matrix protein 2 ectodomain protein bodies in tobacco plants and in insect cells as a candidate universal influenza vaccine. Front. Bioeng. Biotechnol. 2015, 3, 197. [CrossRef]

68. Kim, M.-Y.; Jang, Y.-S.; Yang, M.-S.; Kim, T.-G. High expression of consensus dengue virus envelope glycoprotein domain III using a viral expression system in tobacco. Plant Cell Tissue Organ Cult. 2015, 122, 445-451. [CrossRef] 
69. Gottschamel, J.; Lössl, A.; Ruf, S.; Wang, Y.; Skaugen, M.; Bock, R.; Clarke, J.L. Production of dengue virus envelope protein domain III-based antigens in tobacco chloroplasts using inducible and constitutive expression systems. Plant Mol. Biol. 2016, 91, 497-512. [CrossRef]

70. Kota, S.; Subramanian, M.; Shanmugaraj, B.; Challa, H.; Ponanna, N.M. Subunit vaccine based on plant expressed recombinant Eimeria gametocyte antigen Gam82 elicit protective immune response against chicken coccidiosis. J. Vaccines Vaccin 2017, 8. [CrossRef]

71. Iyappan, G.; Shanmugaraj, B.M.; Inchakalody, V.; Ma, J.K.C.; Ramalingam, S. Potential of plant biologics to tackle the epidemic like situations-Case studies involving viral and bacterial candidates. Int. J. Infect. Dis. 2018, 73, 363. [CrossRef]

72. Yang, M.; Sun, H.; Lai, H.; Hurtado, J.; Chen, Q. Plant-produced Zika virus envelope protein elicits neutralizing immune responses that correlate with protective immunity against Zika virus in mice. Plant Biotechnol. J. 2018, 16, 572-580. [CrossRef] [PubMed]

73. Gunter, C.J.; Regnard, G.L.; Rybicki, E.P.; Hitzeroth, I.I. Immunogenicity of plant-produced porcine circovirus-like particles in mice. Plant Biotechnol. J. 2019, 17, 1751-1759. [CrossRef] [PubMed]

74. Margolin, E.; Chapman, R.; Meyers, A.E.; van Diepen, M.T.; Ximba, P.; Hermanus, T.; Crowther, C.; Weber, B.; Morris, L.; Williamson, A.L.; et al. Production and immunogenicity of soluble plant-produced HIV-1 subtype C envelope gp140 immunogens. Front. Plant Sci. 2019, 10, 1378. [CrossRef]

75. Vaquero, C.; Sack, M.; Chandler, J.; Drossard, J.; Schuster, F.; Monecke, M.; Schillberg, S.; Fischer, R. Transient expression of a tumor-specific single-chain fragment and a chimeric antibody in tobacco leaves. Proc. Natl. Acad. Sci. USA 1999, 96, 11128-11133. [CrossRef]

76. Torres, E.; Vaquero, C.; Nicholson, L.; Sack, M.; Stöger, E.; Drossard, J.; Christou, P.; Fischer, R.; Perrin, Y. Rice cell culture as an alternative production system for functional diagnostic and therapeutic antibodies. Transgenic Res. 1999, 8, 441-449. [CrossRef]

77. Stöger, E.; Vaquero, C.; Torres, E.; Sack, M.; Nicholson, L.; Drossard, J.; Williams, S.; Keen, D.; Perrin, Y.; Christou, P.; et al. Cereal crops as viable production and storage systems for pharmaceutical scFv antibodies. Plant Mol. Biol. 2000, 42, 583-590. [CrossRef]

78. Brodzik, R.; Glogowska, M.; Bandurska, K.; Okulicz, M.; Deka, D.; Ko, K.; van der Linden, J.; Leusen, J.H.; Pogrebnyak, N.; Golovkin, M.; et al. Plant-derived anti-Lewis Y mAb exhibits biological activities for efficient immunotherapy against human cancer cells. Proc. Natl. Acad. Sci. USA 2006, 103, 8804-8809. [CrossRef]

79. Floss, D.M.; Sack, M.; Stadlmann, J.; Rademacher, T.; Scheller, J.; Stöger, E.; Fischer, R.; Conrad, U. Biochemical and functional characterization of anti-HIV antibody-ELP fusion proteins from transgenic plants. Plant Biotechnol. J. 2008, 6, 379-391. [CrossRef]

80. Sainsbury, F.; Lomonossoff, G.P. Extremely high-level and rapid transient protein production in plants without the use of viral replication. Plant Physiol. 2008, 148, 1212-1218. [CrossRef]

81. Holland, T.; Sack, M.; Rademacher, T.; Schmale, K.; Altmann, F.; Stadlmann, J.; Fischer, R.; Hellwig, S. Optimal nitrogen supply as a key to increased and sustained production of a monoclonal full-size antibody in BY-2 suspension culture. Biotechnol. Bioeng. 2010, 107, 278-289. [CrossRef]

82. Huang, Z.; Phoolcharoen, W.; Lai, H.; Piensook, K.; Cardineau, G.; Zeitlin, L.; Whaley, K.J.; Arntzen, C.J.; Mason, H.S.; Chen, Q. High-level rapid production of full-size monoclonal antibodies in plants by a single-vector DNA replicon system. Biotechnol. Bioeng. 2010, 106, 9-17. [CrossRef] [PubMed]

83. Lai, H.; He, J.; Engle, M.; Diamond, M.S.; Chen, Q. Robust production of virus-like particles and monoclonal antibodies with geminiviral replicon vectors in lettuce. Plant Biotechnol. J. 2012, 10, 95-104. [CrossRef] [PubMed]

84. So, Y.; Lee, K.-J.; Kim, D.-S.; Lee, J.-H.; Oh, D.-B.; Hwang, K.-A.; Ko, K.; Choo, Y.-K.; Ko, K. Glycomodification and characterization of anti-colorectal cancer immunotherapeutic monoclonal antibodies in transgenic tobacco. Plant Cell Tissue Organ Cult. 2013, 113, 41-49. [CrossRef]

85. Zeitlin, L.; Bohorov, O.; Bohorova, N.; Hiatt, A.; Kim, D.H.; Pauly, M.H.; Velasco, J.; Whaley, K.J.; Barnard, D.L.; Bates, J.T.; et al. Prophylactic and therapeutic testing of Nicotiana-derived RSV-neutralizing human monoclonal antibodies in the cotton rat model. MAbs 2013, 5, 263-269. [CrossRef] [PubMed]

86. Van Dolleweerd, C.J.; Teh, A.Y.; Banyard, A.C.; Both, L.; Lotter-Stark, H.C.; Tsekoa, T.; Phahladira, B.; Shumba, W.; Chakauya, E.; Sabeta, C.T.; et al. Engineering, expression in transgenic plants and characterisation of E559, a rabies virus-neutralising monoclonal antibody. J. Infect. Dis. 2014, 210, 200-208. [CrossRef] 
87. Lai, H.; He, J.; Hurtado, J.; Stahnke, J.; Fuchs, A.; Mehlhop, E.; Gorlatov, S.; Loos, A.; Diamond, M.S.; Chen, Q. Structural and functional characterization of an anti-West Nile virus monoclonal antibody and its single-chain variant produced in glycoengineered plants. Plant Biotechnol. J. 2014, 12, 1098-1107. [CrossRef]

88. Dent, M.; Hurtado, J.; Paul, A.M.; Sun, H.; Lai, H.; Yang, M.; Esqueda, A.; Bai, F.; Steinkellner, H.; Chen, Q. Plant-produced anti-dengue virus monoclonal antibodies exhibit reduced antibody-dependent enhancement of infection activity. J. Gen. Virol. 2016, 97, 3280-3290. [CrossRef]

89. Vamvaka, E.; Twyman, R.M.; Murad, A.M.; Melnik, S.; Teh, A.Y.-H.; Arcalis, E.; Altmann, F.; Stoger, E.; Rech, E.; Ma, J.K.C.; et al. Rice endosperm produces an underglycosylated and potent form of the HIV-neutralizing monoclonal antibody 2G12. Plant Biotechnol. J. 2016, 14, 97-108. [CrossRef]

90. Shafaghi, M.; Maktoobian, S.; Rasouli, R.; Howaizi, N.; Ofoghi, H.; Ehsani, P. Transient expression of biologically active anti-rabies virus monoclonal antibody in tobacco leaves. Iran. J. Biotechnol. 2018, 16, e1774. [CrossRef]

91. Rattanapisit, K.; Chao, Z.; Siriwattananon, K.; Huang, Z.; Phoolcharoen, W. Plant-produced anti-enterovirus 71 (EV71) monoclonal antibody efficiently protects mice against EV71 infection. Plants 2019, 8, 560. [CrossRef] [PubMed]

92. Rattanapisit, K.; Phakham, T.; Buranapraditkun, S.; Siriwattananon, K.; Boonkrai, C.; Pisitkun, T.; Hirankarn, N.; Strasser, R.; Abe, Y.; Phoolcharoen, W. Structural and in vitro functional analyses of novel plant-produced anti-human PD1 antibody. Sci. Rep. 2019, 9, 15205. [CrossRef] [PubMed]

93. Diamos, A.G.; Hunter, J.G.L.; Pardhe, M.D.; Rosenthal, S.H.; Sun, H.; Foster, B.C.; DiPalma, M.P.; Chen, Q.; Mason, H.S. High level production of monoclonal antibodies using an optimized plant expression system. Front. Bioeng. Biotechnol. 2019, 7, 472. [CrossRef]

94. Hurtado, J.; Acharya, D.; Lai, H.; Sun, H.; Kallolimath, S.; Steinkellner, H.; Bai, F.; Chen, Q. In vitro and in vivo efficacy of anti-chikungunya virus monoclonal antibodies produced in wild-type and glycoengineered Nicotiana benthamiana plants. Plant Biotechnol. J. 2020, 18, 266-273. [CrossRef]

95. Sijmons, P.C.; Dekker, B.M.; Schrammeijer, B.; Verwoerd, T.C.; van den Elzen, P.J.; Hoekema, A. Production of correctly processed human serum albumin in transgenic plants. Biotechnology 1990, 8, 217-221. [CrossRef]

96. Matsumoto, S.; Ikura, K.; Ueda, M.; Sasaki, R. Characterization of a human glycoprotein (erythropoietin) produced in cultured tobacco cells. Plant Mol. Biol. 1995, 27, 1163-1172. [CrossRef]

97. Terashima, M.; Murai, Y.; Kawamura, M.; Nakanishi, S.; Stoltz, T.; Chen, L.; Drohan, W.; Rodriguez, R.L.; Katoh, S. Production of functional human $\alpha 1$-antitrypsin by plant cell culture. Appl. Microbiol. Biotechnol. 1999, 52, 516-523. [CrossRef]

98. Zhong, G.-Y.; Peterson, D.; Delaney, D.E.; Bailey, M.; Witcher, D.R.; Register Iii, J.C.; Bond, D.; Li, C.-P.; Marshall, L.; Kulisek, E.; et al. Commercial production of aprotinin in transgenic maize seeds. Mol. Breed. 1999, 5, 345-356. [CrossRef]

99. Komarnytsky, S.; Borisjuk, N.V.; Borisjuk, L.G.; Alam, M.Z.; Raskin, I. Production of recombinant proteins in tobacco guttation fluid. Plant Physiol. 2000, 124, 927-934. [CrossRef]

100. Ruggiero, F.; Exposito, J.Y.; Bournat, P.; Gruber, V.; Perret, S.; Comte, J.; Olagnier, B.; Garrone, R.; Theisen, M. Triple helix assembly and processing of human collagen produced in transgenic tobacco plants. FEBS Lett. 2000, 469, 132-136. [CrossRef]

101. Staub, J.M.; Garcia, B.; Graves, J.; Hajdukiewicz, P.T.; Hunter, P.; Nehra, N.; Paradkar, V.; Schlittler, M.; Carroll, J.A.; Spatola, L.; et al. High-yield production of a human therapeutic protein in tobacco chloroplasts. Nat. Biotechnol. 2000, 18, 333-338. [CrossRef]

102. De Cosa, B.; Moar, W.; Lee, S.B.; Miller, M.; Daniell, H. Overexpression of the Bt cry2Aa2 operon in chloroplasts leads to formation of insecticidal crystals. Nat. Biotechnol. 2001, 19, 71-74. [CrossRef]

103. Fernandez-San Millan, A.; Mingo-Castel, A.; Miller, M.; Daniell, H. A chloroplast transgenic approach to hyper-express and purify Human Serum Albumin, a protein highly susceptible to proteolytic degradation. Plant Biotechnol. J. 2003, 1, 71-79. [CrossRef]

104. Wirth, S.; Calamante, G.; Mentaberry, A.; Bussmann, L.; Lattanzi, M.; Barañao, L.; Bravo-Almonacid, F. Expression of active human epidermal growth factor (hEGF) in tobacco plants by integrative and non-integrative systems. Mol. Breed. 2004, 13, 23-35. [CrossRef]

105. Ding, S.H.; Huang, L.Y.; Wang, Y.D.; Sun, H.C.; Xiang, Z.H. High-level expression of basic fibroblast growth factor in transgenic soybean seeds and characterization of its biological activity. Biotechnol. Lett. 2006, 28, 869-875. [CrossRef] 
106. Arlen, P.A.; Falconer, R.; Cherukumilli, S.; Cole, A.; Cole, A.M.; Oishi, K.K.; Daniell, H. Field production and functional evaluation of chloroplast-derived interferon-alpha2b. Plant Biotechnol. J. 2007, 5, 511-525. [CrossRef] [PubMed]

107. Kim, T.G.; Baek, M.Y.; Lee, E.K.; Kwon, T.H.; Yang, M.S. Expression of human growth hormone in transgenic rice cell suspension culture. Plant Cell Rep. 2008, 27, 885-891. [CrossRef]

108. Oey, M.; Lohse, M.; Kreikemeyer, B.; Bock, R. Exhaustion of the chloroplast protein synthesis capacity by massive expression of a highly stable protein antibiotic. Plant J. 2009, 57, 436-445. [CrossRef]

109. Xu, J.; Okada, S.; Tan, L.; Goodrum, K.J.; Kopchick, J.J.; Kieliszewski, M.J. Human growth hormone expressed in tobacco cells as an arabinogalactan-protein fusion glycoprotein has a prolonged serum life. Transgenic Res. 2010, 19, 849-867. [CrossRef]

110. An, N.; Ou, J.; Jiang, D.; Zhang, L.; Liu, J.; Fu, K.; Dai, Y.; Yang, D. Expression of a functional recombinant human basic fibroblast growth factor from transgenic rice seeds. Int. J. Mol. Sci. 2013, 14, 3556-3567. [CrossRef]

111. Guan, C.; Du, X.; Wang, G.; Ji, J.; Jin, C.; Li, X. Expression of biologically active anti-thrombosis protein lumbrokinase in edible sunflower seed kernel. J. Plant Biochem. Biotechnol. 2014, 23, 257-265. [CrossRef]

112. Tan, Y.; Wang, K.Y.; Wang, N.; Li, G.; Liu, D. Ectopic expression of human acidic fibroblast growth factor 1 in the medicinal plant, Salvia miltiorrhiza, accelerates the healing of burn wounds. BMC Biotechnol. 2014, 14, 74. [CrossRef] [PubMed]

113. Limkul, J.; Misaki, R.; Kato, K.; Fujiyama, K. The combination of plant translational enhancers and terminator increase the expression of human glucocerebrosidase in Nicotiana benthamiana plants. Plant Sci. 2015, 240, 41-49. [CrossRef] [PubMed]

114. Su, J.; Sherman, A.; Doerfler, P.A.; Byrne, B.J.; Herzog, R.W.; Daniell, H. Oral delivery of Acid Alpha Glucosidase epitopes expressed in plant chloroplasts suppresses antibody formation in treatment of Pompe mice. Plant Biotechnol. J. 2015, 13, 1023-1032. [CrossRef] [PubMed]

115. Wang, Y.P.; Wei, Z.Y.; Zhong, X.F.; Lin, C.J.; Cai, Y.H.; Ma, J.; Zhang, Y.Y.; Liu, Y.Z.; Xing, S.C. Stable expression of basic fibroblast growth factor in chloroplasts of tobacco. Int. J. Mol. Sci. 2016, 17, 19. [CrossRef]

116. Castiglia, D.; Sannino, L.; Marcolongo, L.; Ionata, E.; Tamburino, R.; De Stradis, A.; Cobucci-Ponzano, B.; Moracci, M.; La Cara, F.; Scotti, N. High-level expression of thermostable cellulolytic enzymes in tobacco transplastomic plants and their use in hydrolysis of an industrially pretreated Arundo donax L. biomass. Biotechnol. Biofuels 2016, 9, 154. [CrossRef]

117. Rattanapisit, K.; Abdulheem, S.; Chaikeawkaew, D.; Kubera, A.; Mason, H.S.; Ma, J.K.; Pavasant, P.; Phoolcharoen, W. Recombinant human osteopontin expressed in Nicotiana benthamiana stimulates osteogenesis related genes in human periodontal ligament cells. Sci. Rep. 2017, 7, 17358. [CrossRef]

118. Ahmad, A.R.; Kaewpungsup, P.; Khorattanakulchai, N.; Rattanapisit, K.; Pavasant, P.; Phoolcharoen, W. Recombinant human dentin matrix protein 1 (hDMP1) expressed in Nicotiana benthamiana potentially induces osteogenic differentiation. Plants 2019, 8, 566. [CrossRef]

119. Menary, J.; Hobbs, M.; Mesquita de Albuquerque, S.; Pacho, A.; Drake, P.M.W.; Prendiville, A.; Ma, J.K.; Fuller, S.S. Shotguns vs Lasers: Identifying barriers and facilitators to scaling-up plant molecular farming for high-value health products. PLOS ONE 2020, 15, e229952. [CrossRef]

120. Twyman, R.M.; Stoger, E.; Schillberg, S.; Christou, P.; Fischer, R. Molecular farming in plants: Host systems and expression technology. Trends Biotechnol. 2003, 21, 570-578. [CrossRef]

121. Yusibov, V.; Rabindran, S. Recent progress in the development of plant derived vaccines. Expert Rev. Vaccines 2008, 7, 1173-1183. [CrossRef] [PubMed]

122. Gleba, Y.; Klimyuk, V.; Marillonnet, S. Viral vectors for the expression of proteins in plants. Curr. Opin. Biotechnol. 2007, 18, 134-141. [CrossRef] [PubMed]

123. Qiu, X.; Wong, G.; Audet, J.; Bello, A.; Fernando, L.; Alimonti, J.B.; Fausther-Bovendo, H.; Wei, H.; Aviles, J.; Hiatt, E.; et al. Reversion of advanced Ebola virus disease in nonhuman primates with ZMapp. Nature 2014, 514, 47-53. [CrossRef] [PubMed]

124. Rosales-Mendoza, S. Will plant-made biopharmaceuticals play a role in the fight against COVID-19? Expert Opin. Biol. Ther. 2020, 20, 545-548. [CrossRef]

125. Shanmugaraj, B.; Siriwattananon, K.; Wangkanont, K.; Phoolcharoen, W. Perspectives on monoclonal antibody therapy as potential therapeutic intervention for Coronavirus disease-19 (COVID-19). Asian Pac. J. Allergy Immunol. 2020, 38, 10-18. 
126. Capell, T.; Twyman, R.M.; Armario-Najera, V.; Ma, J.K.C.; Schillberg, S.; Christou, P. Potential applications of plant biotechnology against SARS-CoV-2. Trends Plant Sci. 2020, 25, 635-643. [CrossRef]

127. Buyel, J.F. Plant molecular farming-Integration and exploitation of side streams to achieve sustainable biomanufacturing. Front. Plant Sci. 2018, 9, 1893. [CrossRef] [PubMed]

128. Maliga, P. Engineering the plastid genome of higher plants. Curr. Opin. Plant Biol. 2002, 5, 164-172. [CrossRef]

129. Bock, R. Plastid biotechnology: Prospects for herbicide and insect resistance, metabolic engineering and molecular farming. Curr. Opin. Biotechnol. 2007, 18, 100-106. [CrossRef]

130. Jin, S.; Daniell, H. The engineered chloroplast genome just got smarter. Trends Plant Sci. 2015, 20, 622-640. [CrossRef]

131. Zhang, B.; Shanmugaraj, B.; Daniell, H. Expression and functional evaluation of biopharmaceuticals made in plant chloroplasts. Curr. Opin. Chem. Biol. 2017, 38, 17-23. [CrossRef] [PubMed]

132. Xu, J.; Zhang, N. On the way to commercializing plant cell culture platform for biopharmaceuticals: Present status and prospect. Pharm. Bioprocess. 2014, 2, 499-518. [CrossRef]

133. Tekoah, Y.; Shulman, A.; Kizhner, T.; Ruderfer, I.; Fux, L.; Nataf, Y.; Bartfeld, D.; Ariel, T.; Gingis-Velitski, S.; Hanania, U.; et al. Large-scale production of pharmaceutical proteins in plant cell culture-The protalix experience. Plant Biotechnol. J. 2015, 13, 1199-1208. [CrossRef] [PubMed]

134. Santos, R.B.; Abranches, R.; Fischer, R.; Sack, M.; Holland, T. Putting the spotlight back on plant suspension cultures. Front. Plant Sci. 2016, 7, 297. [CrossRef] [PubMed]

135. Gurusamy, P.D.; Schafer, H.; Ramamoorthy, S.; Wink, M. Biologically active recombinant human erythropoietin expressed in hairy root cultures and regenerated plantlets of Nicotiana tabacum L. PLoS ONE 2017, 12, e0182367. [CrossRef] [PubMed]

136. Gutierrez-Valdes, N.; Häkkinen, S.T.; Lemasson, C.; Guillet, M.; Oksman-Caldentey, K.-M.; Ritala, A.; Cardon, F. Hairy root cultures-A versatile tool with multiple applications. Front. Plant Sci. 2020, 11, 33. [CrossRef] [PubMed]

(C) 2020 by the authors. Licensee MDPI, Basel, Switzerland. This article is an open access article distributed under the terms and conditions of the Creative Commons Attribution (CC BY) license (http://creativecommons.org/licenses/by/4.0/). 